JUL 121989

ORNL/TM-11155

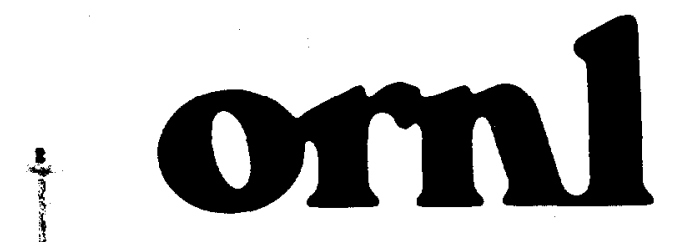

OAK RIDGE
NATONAL
LABORATORY
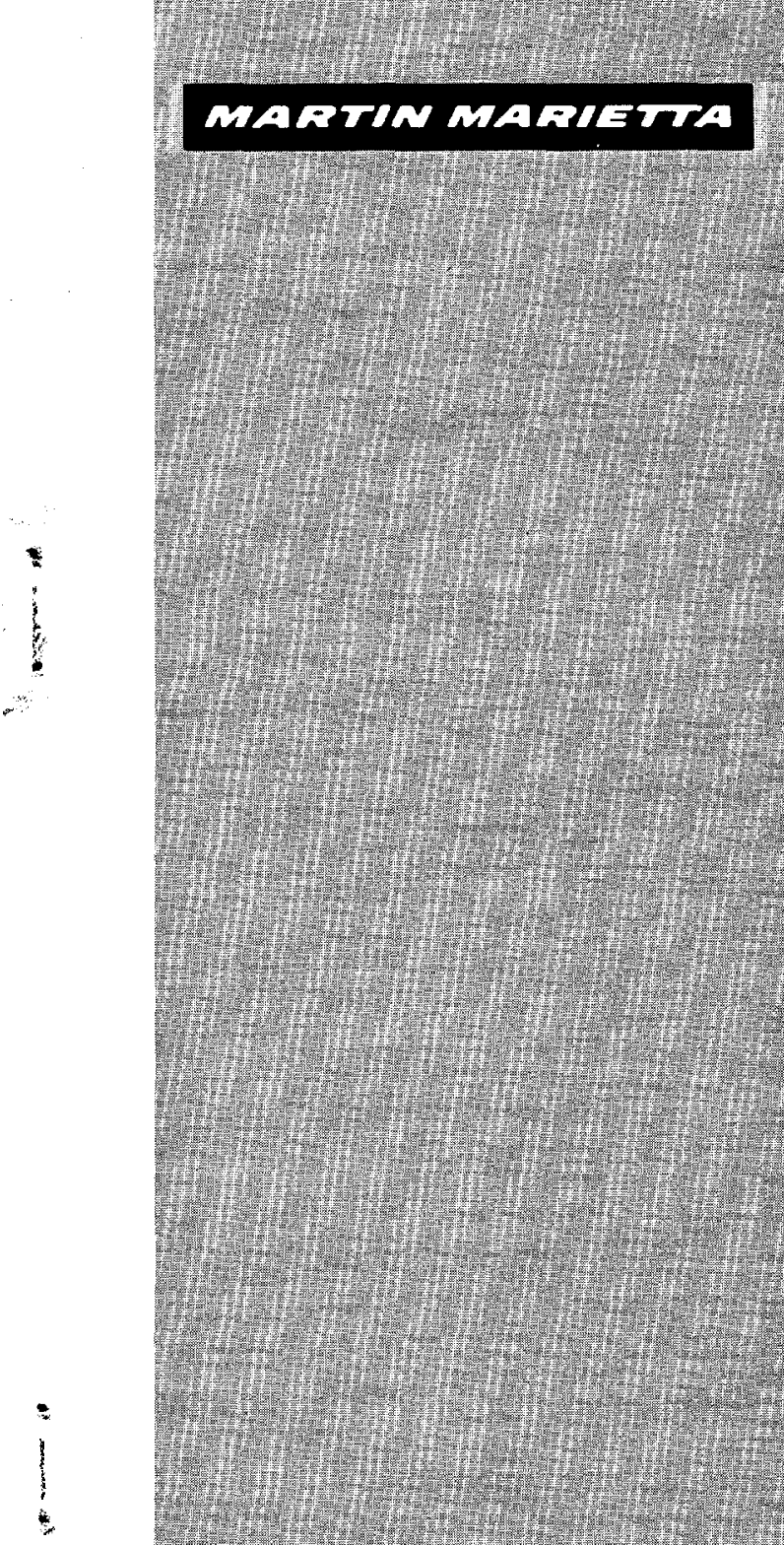

\section{The Transfer and Diffusion of New Technologies: A Review of the Economics Literature}

\author{
T. R. Curlee \\ R. K. Goel
}

OPERATEO BY

MARTIN MARIETTA ENERGY SYSTEMS, INC. FOR THE UNIEO STATES OEPARTMENT OF ENERBY 
This report has been reproduced directly from the best available copy.

Available to DOE and DOE contractors from the Office of Scientific and Technical Information, P.O. Box 62, Oak Ridge, TN 37831; prices available from (615) 576-840 1, FTS 626-840 1.

Available to the public from the National Technical Information Service, U.S. Department of Commerce, 5285 Port Royal Rd., Springfield, VA 22161.

NTIS price codes-Printed Copy: A04 Microfiche A01

This report was prepared as an account of work sponsored by an agency of the United States Government. Neither the United States Government nor any agency thereof, nor any of their employees, makes any warranty, express or implied, or assumes any legal liability or responsibility for the accuracy, completeness, or usefulness of any information, apparatus, product, or process disclosed, or represents that its use would not infringe privately owned rights. Reference herein to any specific commercial product, process, or service by trade name, trademark, manufacturer, or otherwise, does not necessarily constitute or imply its endorsement, recommendation, or favoring by the United States Government or any agency thereof. The views and opinions of authors expressed herein do not necessarily state or reflect those of the United States Government or any agency thereof. 
THE TRANSFER AND DIFFUSION OF NEW TECHNOLOGIES:

A REVIEW OF THE ECONOMICS LITERATURE

\author{
T. Randall Curlee \\ and \\ Rajeev K. Goel \\ Energy Division
}

Oak Ridge National Laboratory

Oak Ridge, Tennessee 3783 1-6205

Date Published - June 1989

Prepared for

Oak Ridge National Laboratory

Technology Policy Center

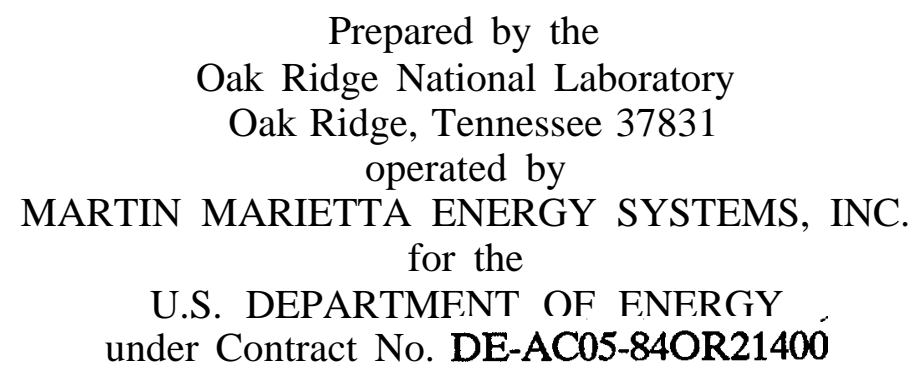



TABLE OF CONTENTS

ABSTRACT $\ldots \ldots \ldots \ldots \ldots \ldots \ldots \ldots \ldots \ldots \ldots \ldots \ldots \ldots \ldots$

1. INTRODUCTION

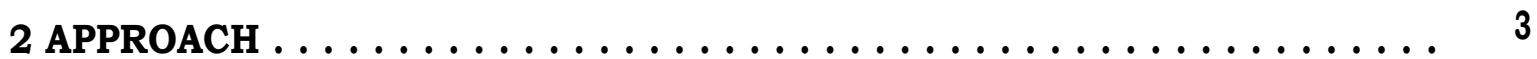

3. OVERVIEW OF THE ECONOMICS PERSPECTIVE ON

TECHNOLOGICALCHANGE $\ldots \ldots \ldots \ldots \ldots \ldots \ldots \ldots, 5$

3.1 THE SCHUMPETER TRILOGY $\ldots \ldots \ldots \ldots \ldots \ldots \ldots \ldots \ldots .5$

3.2 INVENTION AND INNOVATION $\ldots \ldots \ldots \ldots \ldots \ldots \ldots \ldots \ldots$

3.3 DIFFUSION ..................... 7

3.4 POLICY ISSUES RAISED BY ECONOMISTS WITH RESPECT TO

TECHNOLOGICAL CHANGE $\ldots \ldots \ldots \ldots \ldots \ldots \ldots$

3.5 MEASUREMENT ISSUES $\ldots \ldots \ldots \ldots \ldots \ldots \ldots \ldots \ldots \ldots \ldots$

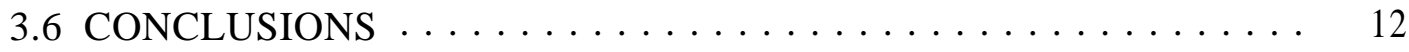

4. THE PUBLIC-PRIVATE INTERFACE $\ldots \ldots \ldots \ldots \ldots \ldots \ldots \ldots \ldots$

4.1 INTRODUCTION $\ldots \ldots \ldots \ldots \ldots \ldots \ldots \ldots \ldots \ldots \ldots \ldots \ldots \ldots$

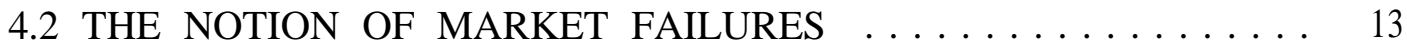

4.3 PUBLIC POLICY RESPONSES TO MARKET FAILURES . . . . . . 15

4.3.1 Indirect Intervention $\ldots \ldots \ldots \ldots \ldots \ldots \ldots \ldots \ldots .15$

4.3.1.1 Antitrust Policies . . . . . . . . . . . . 15

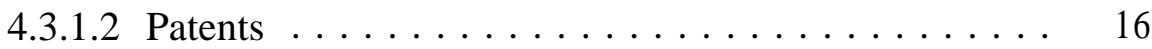

4.3.1.3 Standardization .................. . . 17

4.3.1.4 Provision of Information . . . . . . . . . . . . 17

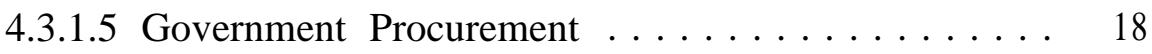

4.3.1.6 Taxes and Subsidies _................ 18

4.3.2 Direct Intervention ................... 19

4.3.2.1 Points at which the Public-Private Interface Can Occur ...................... 19

4.3.2.2 Public-Private Sector Joint Ventures . . . . . . . . 21

4.3.2.3 Public Sector Invention, Innovation, and Diffusion . . 22

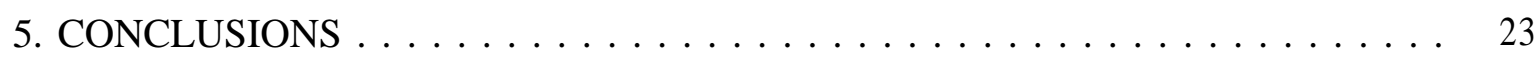

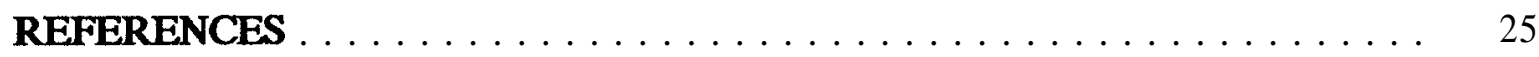

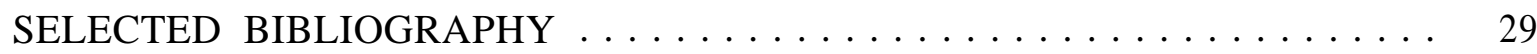

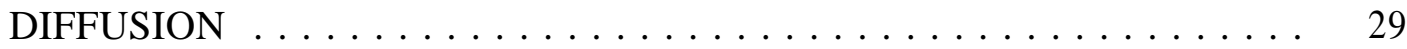

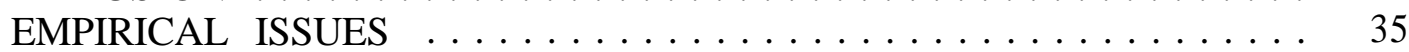

PATENTS AND PUBLIC POLICY . ................ 39

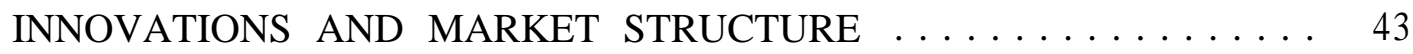

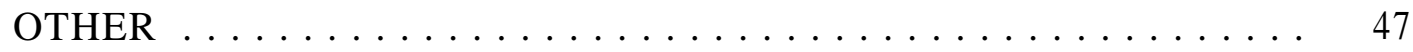




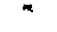

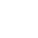

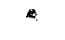




\begin{abstract}
This report presents a general overview of the economics literature on technological change and focuses particularly on the interface between the public and private sectors in promoting the transfer and diffusion of new technologies.

Our ability to transfer and diffuse new technologies is generally recognized as a key to increased productivity in the United States and this country's ability to compete internationally. A great deal of research has been done on technology transfer and diffusion by various disciplines and from numerous perspectives. Unfortunately, the policy implications of those different works are not always consistent. Further, the different disciplines have difficulty in communicating even when addressing the same issues and drawing the same general conclusions.

The primary objective of this report is to lessen the chasm among the disciplines with respect to technology transfer and diffusion by summarizing the perspectives presented in the economics literature. The document is intended primarily for an interdisciplinary audience.

The discussion begins with an overview of the economics literature on technological change and focuses on what economists commonly refer to as the Schumpeter trilogy -i.e., invention, innovation, and diffusion. Economists typically view technological change to occur in these three distinct steps and have formulated conceptual frameworks that suggest how and why each step in the process of technological change takes place. After defining these three steps, the report presents brief overviews of the seminal conceptual and empirical works in the three areas. Of key concern is an overview of the types of questions historically posed by economists and the degree to which economists have reached a consensus on these questions.
\end{abstract}

The report then abstracts from this larger picture of technological change and focuses specifically on the interface between the public and private sectors. Within this second thrust, the report poses and attempts to answer two general questions: (1) Why have economists argued for government involvement to promote technological change? This issue leads to a brief discussion of market failures that inhibit the invention, innovation, and diffusion of new technologies. (2) Where and how can the public sector interface with the private sector to correct the market failures or, alternatively, take actions to counteract the effects of market failures?

The role of the federal government in the innovative process remains the subject of significant debate by economists. Although most economists would agree that some role must be played by the public sector, our current conceptual and empirical knowledge is lacking. Little consensus has thus been reached about how the government should respond to the problem in general, and even less consensus exists about how particular technologies in particular markets should be dealt with. 
The report suggests that the public sector can encourage the process of innovation by either directly participating in the process of technical change or by indirectly stimulating the private sector's innovative activities. Although both methods have been shown to promote technical change, economists have not yet developed a generally agreed upon formula that dictates what method is most appropriate in any given case.

It is likely that the arguments by economists with respect to the government's role in technological change will become more definitive as more detailed conceptual and empirical studies are completed. It is unlikely, however, due to the number of dynamic factors that are known to influence the innovative process, that the economics profession will develop a formula or set of formulae for promoting technical change or the involvement of the public sector in that change. A movement toward interdisciplinary research, which is currently underway, is the most promising avenue for studying the role of public policy in promoting technical change. 


\section{INTRODUCTION}

Our ability to transfer and diffuse new technologies is generally recognized as a key to increased productivity in the United States and this country's ability to compete internationally. A great deal of work has been done on technology transfer and diffusion by various disciplines from numerous perspectives. Unfortunately, in examining that literature, one is struck not only by the different policy recommendations made with respect to particular issues, but also by the obvious inabilities of the different disciplines to communicate even when addressing the same issues and drawing the same general conclusions. ${ }^{1}$

A primary goal of this report is to lessen this chasm among the disciplines with respect to technology transfer and diffusion by summarizing the perspectives presented in the economics literature on the subject. Although intended for an interdisciplinary audience, the content of the report will also hopefully be of value to the economist interested in an overview of the subject.

A primary focus of this work is on the interface between the public and private sectors in the transfer and diffusion of new technologies developed within or facilitated by the public sector. The specific policy instruments that can be used to facilitate the transfer and diffusion process are discussed with respect to their specific pros and cons. Also discussed are the policy instruments available to facilitate the transfer and diffusion of new technologies developed within the private sector.

A secondary focus of this report is on the major thrust areas addressed by economists with respect to the broader issues associated with the innovative process. This general discussion is important because it not only suggests the types of issues believed to be important by economists, but also why those issues are argued to be important. The general discussion also contributes to a better understanding of why specific policy instruments have been advocated by economists. It is not, however, the purpose of this report to provide a definitive review of the economics literature on the general topic of innovation. Rather, the general discussion is provided as a means to focus on the more narrow topic of the public/private interface to transfer and diffuse new technologies.

${ }^{1} \mathrm{~A}$ good example of our inabilities to communicate across disciplinary lines is illustrated when reading the National Science Foundation's (1983) so-called "Red Book." 


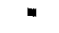

.

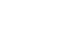




\section{APPROACH}

The discussion begins with an overview of the economics literature on technological change and focuses on what economists commonly refer to as the Schumpeter trilogy-i.e., invention, innovation, and diffusion (see Stoneman, 1983). Economists typically view technological change to occur in these three distinct steps and have formulated conceptual frameworks that suggest how and why each step in the process of technological change takes place. After defining these three steps, the report presents brief overviews of the seminal conceptual and empirical works in the three dimensions of technical change. Of key concern is an overview of the types of questions historically posed by economists and the degree to which economists have reached a consensus on these questions and their answers.

The report then abstracts from this larger picture of technological change and focuses specifically on the interface between the public and private sectors. Within this second thrust, the report poses and attempts to answer two general questions: (1) Why have economists argued for government involvement to promote technological change? This issue leads to a brief discussion of market failures that inhibit the invention, innovation, and diffusion of new technologies. (2) Where and how can the public sector interface with the private sector to correct market failures or, alternatively, take actions to counteract the effects of market failures? It is argued that government intervention can take two main avenues--(a) by regulating the private sector and thereby altering private-sector incentives and disincentives such that the private sector itself performs the function of technological change in a way that is closer to the social optimum; and (b) by the government itself participating directly in technological changes, or, in other words, by having the government participate directly in the invention, innovation, and/or diffusion steps. If the public sector takes the regulatory approach, numerous policy instruments are available to address the relevant market failures. If the public sector takes the second approach, the government's activities must eventually interface with the private sector if those activities are to be realized as technological progress in the private sector. Appropriate considerations are the relative advantages of different policy instruments and the point--i.e., invention, innovation, or diffusion--at which the interface should occur. 


\section{.}




\section{OVERVIEW OF THE ECONOMICS PERSPECTIVE ON TECHNOLOGICAL CHANGE}

\subsection{THE SCHUMPETER TRILOGY}

Economists typically think of technological change as occurring in three phases commonly known as the Schumpeter Trilogy--i.e., invention, innovation, and diffusion. Invention, which is often depicted as an exogenous occurrence, refers to the generation of a new idea or new concept that may lead to a new product or process. Innovation follows invention and is said to be accomplished when (1) the idea from invention is developed into a new product or process, and (2) the new product or process is first commercially transferred. Diffusion refers to the process by which the new process or product spreads across firms within a market and across markets.

Schumpeter's work and the resulting steps of technical change were focused on the relationship between market structure and technical change. Schumpeter (1947) postulated that concentrated industries were more suitable for rapid technical change. Monopolies were argued to be better able to bear the risks of an uncertain innovation process and have the resources for a sustained research effort. Since Schumpeter's seminal piece, numerous theoretical and empirical studies have addressed these basic questions. Unfortunately, no consensus has emerged on whether to accept or reject the Schumpeter hypothesis. The main reason for the continuing debate is a lack of $R \& D$ data. We address the notion of market structure and technical change further below. At this point we focus on the conceptual and empirical economics literature that has addressed the three steps in the Schumpeter trilogy.

\subsection{INVENTION AND INNOVATION}

The general theories of invention and innovation fall into two broad categories-neoclassical theory and evolutionary theory. Neoclassical theory asserts that invention and innovation occur as a result of the drive for maximum profits. ${ }^{2}$ Firms are said to innovate ${ }^{3}$ in response to two types of forces--demand pull and technology push. Demand-pull technological change occurs when innovators respond to the perceived needs of the market. For example, a firm's marketing department supposedly identifies technological needs and directs the development of new technologies in response to those needs. Potential profitability from the new product or process provides the incentive for the firms to innovate under the demand-pull hypothesis. The demand-pull hypothesis suggests that

\footnotetext{
${ }^{2}$ The proponents of neoclassical theory of technical change include Arrow (1962) and Kamien and Schwartz (1974 and 1976).

${ }^{3}$ Here we are using the term innovate in the generic sense to include both invention and innovation.
} 
firms with large marketing and research facilities have advantages over firms with smaller marketing and research facilities.

Technology-push technical. change occurs because of a rapid rate of growth in "know-how," which in turn leads to better processes and products. This theory suggests that technical change originates within the firm's R\&D department and is not focused in its initial phase on fulfilling the specific needs of any specific potential client. Rather, new technologies result from a better understanding of more basic technological knowledge. Kamien and Schwartz (1982) suggest that the technology-push hypothesis has two broad implications: (1) Firms with larger R\&D facilities are better able to exploit potentially feasible research projects than firms with smaller research departments; and (2) the general rate of increase in the scientific base has a direct effect on the rate of technological change. Kamien and Schwartz go on to suggest that technology-push and demand-pull are not competing hypotheses, but rather examine different sides of the bigger innovation picture. Technology-push can be seen as a long-run theory and demand-pull as a

short-run theory. At present the conventional wisdom appears to be that demand-pull is more important to overall technological change than is technology-push. ${ }^{4}$

The somewhat simplistic view of technological change under neoclassical theory has come under attack in recent years. It has been suggested that neoclassical theory's emphasis on profit maximization is satisfactory at predicting macroeconomic technical change but does not adequately address how technological change occurs at the microeconomic level. In other words, neoclassical theory is unable to reconcile aggregate economy-wide technical change with firm-specific technical change. Evolutionary theory, mainly due to Richard Nelson and Sidney Winter, attempts to reconcile the problems posed by neoclassical theory (see Nelson and Winter, 1982). Evolutionary theory suggests that producers of products and developers of processes follow a set of routines in their efforts to improve existing products and processes. Such pursuit is said to lead to innovations. According to Nelson (1987) "...by an evolutionary theory we mean to include a relatively large class of models of change, with evolutionary theory in biology being a special case, and evolutionary theory of technical change being another special case.... Our theory (evolutionary) might be regarded as a special case of analysis of cultural evolution, where market values play an essential role and profit is the figure of merit, and where competitive pressures work to cut back unprofitable entities and augment profitable ones."

In summary, the neoclassical assertion that profits motivate technical change has generally been found to be true, though it does not explain all technical change--for example, serendipity. The more recent evolutionary theory attempts to address these shortcomings by adopting a more interdisciplinary approach. Unfortunately, while this new theory presents a more accurate representation of the real world, it also presents complicated hypotheses that are often difficult to test empirically because of data

${ }^{4}$ Note that technology-push and demand-pull technology change are not "water-tight" compartments. A technical change can result from both demand-pull and technology-push. 
limitations. Although the new approach is promising, it is still being developed and has, thus far, not provided answers that are commonly accepted.

\subsection{DIFFUSION}

Stoneman (1986) defines diffusion as "the process by which innovations (be they new products, new processes, or new management methods) spread within and across firms." The literature on diffusion for the most part attempts to rationalize why a new technology that is superior to an old technology is not adopted immediately by all potential adopters.

Numerous factors, mostly based on common sense, have been suggested to affect the diffusion process. For example, Rosenberg (1976) mentions the following. First, new technologies take time to establish their superiority over existing technologies. This is, partly due to the fact that new technologies are not perfect when they are introduced and partly due to information about the new technologies that is not totally accurate or at a minimum not perceived to be accurate by potential adopters. Second, new technologies often require complex skills by the users, and such skills are developed over time. Third, the new technology may be complicated to manufacture or implement, requiring time for adaptations. Fourth, many new technologies cannot be implemented successfully unless required complementary products or processes are invented or improved. Fifth, improvements in old technologies may extend the lives of those technologies making the move to the new technology less attractive. Sixth, potential adopters may be dispersed geographically requiring increased marketing costs and also greater testing in areas of varying climates.

On a more formal level, several models of diffusion have been published which fit into two main schools of thought. One school of thought is based on Griliches' seminal 1957 paper; another is based on the work of Edwin Mansfield and his associates? According to Griliches (1957), the relationship between the diffusion of a new technology and time plots like an " $\mathrm{S}$ " shaped or sigmoid curve, implying that the rate of diffusion increases at a diminishing rate eventually after initially increasing at an increasing rate. ${ }^{6}$ Griliches arrived at his conclusions while studying the factors affecting the variance in the diffusion of hybrid corn in the United States. Griliches moved the notion of technological diffusion from something not explained very well within the neoclassical framework to a process that could be shown to obey forces based on profit maximization. According to

${ }^{5}$ It is interesting to note that early works on technological change, such as Schumpeter's (1947) seminal piece, did not explicitly outline the forces affecting diffusion. Schumpeter's reasoning of the diffusion process was that potential profitability leads someone to innovate, and this profitability from the new technology induces other firms to imitate, thus resulting in diffusion.

${ }^{6}$ Note that a "S" shaped curve can take on various mathematical forms. The logistic and lognormal curves are commonly used. 
Griliches, "the "process of adopting and distributing a particular invention to different markets and its acceptance by entrepreneurs, is amenable to economic analysis. It is possible to account for a large share of the spatial and chronological differences in the use of hybrid corn with the help of "economic" variables. The lag in the development of adaptable hybrids for particular areas and the lag in the entry of seed producers into these areas can be explained on the basis of varying profitability of entry. Also, differences in both the long-run equilibrium use of hybrids and the rate of approach to that equilibrium level are explainable, at least in part, by differences in the profitability of the shift from open pollinated to hybrid varieties."

Although Griliches' approach was a step in the right direction, it simply asserted that diffusion follows an "S" shaped curve and ignored the basic question of why that pattern is typically followed. It also ignored such questions as (1) will different innovations have different diffusion curves, and (2) what specific characteristics of the technology and the sectors adopting and disseminating the technology--other than profitability--are important in determining the specific diffusion path?

In an attempt to address why diffusion follows a "S" shaped curve, Mansfield, in his 1968 book, put forth the idea of epidemic theory. Basically, Mansfield asserted that the process of technological diffusion can be likened to medical epidemics, which, given special characteristics, can be shown conceptually to generate a " $\mathrm{S}$ " shaped curve. In other words, diffusion occurs over time as more and more firms come in contact with those who have already adopted a new technology. A somewhat similar approach, known as the Bayesian approach, has been advocated by Stoneman (1983). According to this theory, firms learn in a Bayesian ${ }^{7}$ way from their experience. Over time firms learn about the characteristics of the new technology, which alters the desired level of use. Both Mansfield's and Stoneman's approaches are based on the notion that information, cost of adoption, and uncertainty are keys to why firms do not immediately switch to a new technology. Information spreads like an epidemic and reduces the associated uncertainty, thus increasing the acceptability of the new technology to potential adopters.

Numerous papers have extended the basic arguments discussed above to include additional economic variables and to test specific hypotheses. For example, Reinganum (1981) modeled diffusion among firms as an oligolopy game in which firms maximize the present discounted value of future profits by undertaking strategic behavior.8 Reinganum

${ }^{7}$ Bayesian updating is where the decision-makers use their past experience to change their judgements about substitutes. These changes, such as the probability that a new product replaces an old, may alter their future actions.

${ }^{8}$ Oligopoly is a type of market structure between the extremes of competition and monopoly. In competition no single firm is large enough to have an impact on market prices. In monopoly one firm controls the entire market. In an oligopoly, there are a few interdependent firms who either collectively or individually set the industry price. The firms within that market play strategic games which may determine market prices, or in the case of Reinganum (1981) determine the time path of diffusion. 
suggests that potential profits to be gained from adopting a new technology decline as the number of firms that have already adopted the technology increases, leading to the typical diffusion time path. Jensen (1982) developed a conceptual model of diffusion to show that firms may delay adoption of an invention if there is uncertainty with respect to the profitability of the new technology. Hannan and McDowell (1987) examined the adoption of automatic teller machines by U.S. banks and found that more concentrated banking markets reacted more strongly to rival adoption than banks in less concentrated markets. Other authors, such as Easingwood (1988), have attempted to monitor the diffusion of different new technologies. Easingwood developed seven classes of diffusion rates and found that the time required to achieve $75 \%$ market penetration ranges form 3.5 years to 28.4 years.

Economists have made progress in the study of technological diffusion in the past three decades. Unfortunately, due to the number of dynamic factors affecting diffusion, economists have not been able to develop a simple formula or set of formulae to explain technology diffusion. Factors such as market structure, business cycles, adoption costs, expectations, and so forth are changing constantly. A given new technology has to be evaluated by taking all of these factors into account. And not only do the relevant factors have to be identified, those factors must also be quantified. In the words of Stoneman (1986), "Different innovations in different industries will have different diffusion patterns (agriculture is not like aircraft); public corporation may behave different from private firms; and the regulatory environment may also affect the diffusion process."

Economists have, however, drawn some general conclusions from a more aggregate perspective. For example, Kamien and Schwartz (1982) have stated that while "There are few studies of the relationship between market structure and rate of diffusion of innovation,... they all appear to indicate that the rate of process innovation diffusion is positively related to the competitiveness of the industry into which it is introduced." Mansfield (1968) argued that the number of adopters of a new technology is a function of the adoption risk, the expected profitability of the acquisition, and the number of potential adopters. Greater adoption risk is generally recognized to slow the diffusion process, as do lower potential profitability and a greater number of potential adopters. Other factors found to influence diffusion rates include absolute capital requirements, the durability of the adopting industry's capital stock, the industry's rate of sales growth, the complexity of the new technology, the cost of information dissemination, and the stage of the overall business cycle.

\subsection{POLICY ISSUES RAISED BY ECONOMISTS WITH RESPECT TO TECHNOLOGICAL CHANGE}

The major policy issue raised by economists with respect to technological change has to do with the relationship between market structure and inventive, innovative, and diffusion activities. Given that policy makers desire optimal technical advances and can directly and indirectly adopt policies that impact on the structure of markets, the relationship between market structure and technological advance is of crucial importance to an overall technology-policy. 
The relationship was first postulated by Schumpeter (1947) when he suggested that concentrated industries are more suited for rapid technical change. It was suggested that monopolies are better able to bear the risks of research and development and have the resources to move new technologies to market or create new markets. As stated above, although numerous economic assessments on the subject have been completed, a consensus opinion on the validity of Schumpeter's hypothesis has not been reached.'

Market structure involves various parameters, but most often refers to the number of firms and the power of those firms in the market." For example, in a bilateral monopoly market, a single buyer faces a single seller. In a purely competitive market no one producer or consumer is large enough to exert any control on market prices. A number of market structures exist between these two extremes and are referred to as oligopolies. Within an oligopolistic structure, producers with equal or varying market power take actions as if in a game to maximize some objective. Strategic maneuvers can also take place among producers and consumers. A common oligopolistic structure used in the conceptual literature is the Stackelberg structure in which the market consists of one dominant producer and many fringe firms that exert no market control individually.

Economists generally recognize that the relationship between market structure and technological change is nonlinear and goes in both directions. ${ }^{11}$ For example, too much. competition for a new product or process may induce premature introduction, while a, monopolist may delay the introduction of its new technology [Barzel (1968)]. With regard to the effect of technological change on market structure, arguments fall into two main schools of thought. One school maintains that innovations create entry barriers by making it harder for potential entrants to raise finances for research and development. Incumbent firms are also said to have an advantage in terms of having established research facilities and investments in human capital. This effect is reinforced by learning by doing, or the improvement in efficiency gained with experience (see Levin, 1978). The other school of thought is of the view that innovations promote competition by enabling small firms to attack established markets through new products [see Kamien and Schwartz $(1975,1982)$ for literature reviews]. In reality, innovations serve both functions. The extent of influence of innovations on market structure has been shown to depend on,

'See, for example, Kamien and Schwartz (1975 and 1982), Nelson and Winter (1978), Loury (1979), Futia (1980), Lee and Wilde (1980), Dasgupta and Stiglitz (1980a,b), Tandon (1984), Reinganum (1985), Dorfman (1987), and Goel (1987).

" "For measures of composition of markets, such as concentration ratios and Mirfindahl indices, see, for example, Scherer (1980). Other market structure parameters include vertical and horizontal integration, which in the case of vertical integration indicates the degree to which firms are involved with various production steps in the production of a product and in the case of horizontal integration indicates the involvement of the firms in other markets.

'See, for example, Goel (1987), Reinganum (1985), Dasgupta and Stiglitz (1980a,b), Lee and Wilde (1980), and Loury (1979). 
among other things, the type of innovation, the type of market, and timing of introduction. For example, Lunn (1986) found that process and product innovations have different effects in terms of industrial concentration. Specifically, Lunn's conclusions are (1) there is a positive relation between concentration and process patenting, while the same is not true for product patenting; and (2) there is a weak positive link between advertising and product patenting.

Numerous studies and differing conclusions also exist with respect to the impact of market structure on technological change. For example and on the one hand, Angelmar (1985) found in a cross-sectional study of 160 business units that concentration had a negligible impact on research investment. On the other hand, Levin and Reiss (1984) empirically tested the Schumpeterian hypothesis for 2 and 3 digit SIC industries in the United States and found support for a direct relationship between research and development and market structure. However, problems with data aggregation have been argued to limit the confidence in the findings of Levin and Reiss. Further, Mansfield (1981) found in a study of 108 firms that more concentrated industries tend to have more interfirm variation in R\&D than less concentrated firms. Dorfman (1987) studied the relationship between market structure and innovations in the computer and semiconductor industries. Her somewhat vague conclusions may represent the current state of the economics literature on the subject. Dorfman states that "It is evident, empirically, that at any given time there may be significant opportunities for innovation of the sort that small, new firms can exploit in markets that they can enter with the expectation of earning a satisfactory return on investment. At the same time there will remain opportunities for innovation that can only be exploited by large firms in protected markets."

\subsection{MEASUREMENT ISSUES}

A major reason for the ambiguity in economic research on technical change is the lack of good data. Data on research and development are scarce and imprecise. Firms are often unwilling to divulge information about their investments in R\&D because such data are proprietary. And even if firms reveal their research expenditures, the measurement of research inputs is not simple. For example, research inputs (including human and non-human inputs) may be used for production purposes and vice versa. Another vexing problem is the measurement of human capital.

In efforts to obtain data on the outputs of research projects, economists have used the number of patents issued as a proxy measure. Unfortunately, this measure is not free of shortcomings. For example, it does not take into account the innovative activity that goes unpatented. Further there is no good way to weigh patents of varying importance. Comanor and Scherer (1969) used three different measures of technical change--number of patents, employment of R\&D personnel, and value of new product sales. The authors found statistically significant positive relationships between patents and the other two 
measures of technical change. Hall et al. (1986) and Griliches et al. (1987) showed strong contemporaneous relationships between $R \& D$ and patenting. ${ }^{12}$

Another approach to the measurement of productivity of research has been the inclusion of $R \& D$ as a separate input in the firm's production process. See, for example, Lucas (1967) and Rasmussen (1973). However, the issue of appropriation of resources between research and other inputs plagues this approach.

\subsection{CONCLUSIONS}

Economists have been less than totally successful in studying invention, innovation, and diffusion either conceptually or empirically. The profession has moved from a position in which the notion of technological change did not fit very well within the profit-maximization neoclassical framework, to a position where profit maximization is recognized as a crucial part of the process--but only a part. Economists now generally recognize that technological change is a complicated process that requires interdisciplinary approaches. While on an aggregated basis, some understanding of the phenomenon and in fact predictive powers can be obtained from simple rules such as profit maximization, the problem is much more difficult to address at the firm and individual market levels. The contributions of the economics literature to a better understanding of technological change are therefore most evident when addressing the "big picture". Economists have not been particularly successful in understanding or predicting the "hows" and "whys" a particular technology is developed or diffuses within a particular market. This may change as better R\&D data become available.

\footnotetext{
${ }^{12}$ For more on patenting, see Scherer (1984).
} 


\section{THE PUBLIC-PRIVATE INTERFACE}

\subsection{INTRODUCTION}

This section moves away from the "big picture" concerning technical change and focuses on the more narrow topic of how the public sector and the private sector interact in the pursuit of technical change. A necessary precursor to this discussion is an explanation of why the public sector should be involved in the first place. Although most disciplines accept the need for government involvement in the process as a given, economists generally agree that the appropriate interaction between the two sectors must be built on an understanding of the problems that call for public sector involvement.

\subsection{THE NOTION OF MARKET FAILURES}

Much of economic theory is devoted to identifying a market structure in which producers and consumers interact in a way such that the allocation of resources is most efficient. The theory goes on to show that if the distribution of factor ownership is "correct", a free-market economy can maximize the social welfare. Unfortunately, the conditions under which such an outcome holds are somewhat restrictive. If certain conditions do not hold, economic theory suggests that the market allocation of resources will neither be most efficient nor welfare maximizing. These conditions are generally referred to as market failures and, in general, call for some form of public sector intervention [see, for example, Hirshleifer (1982), or Stiglitz (1988) for details].

Although an explanation of the theory and specific market failures is beyond the scope of this report, a general discussion of market failures helps to suggest why economists call for particular types of public sector involvement. There are three types of market failures that may result in the private sector's push for technical advance to be something less than the social optimum--(1) the lack of competitive markets, (2) the existence of market externalities, and (3) the lack of contingent commodity markets or failures with respect to information and uncertainty. While these market failures will be discussed in the following subsections on specific policies, a brief discussion of these failures at this point outlines the general types of public intervention called for by economists.

The lack of competitive markets refers to situations in which some of the producers and/or the consumers of a good or service have market power. In other words, some producers and/or consumers are large enough relative to the size of the market to have an influence on the market price. Factors other than size can also lead to market power. In general, the economics literature suggests that the fewer the competitors in a market the more severe the problems of resource allocation and social optima become. This general conclusion does not, however, apply necessarily to the notion of technical change. As discussed in the previous section, the Schumpeter hypothesis states that bigness promotes' 'rapid technical change. And although no consensus has yet been reached 
concerning the Schumpeter hypothesis, technical change may be a case in which a generally recognized market failure, may in fact give results superior to pure competition.

Economists do not, at this time, agree about the effects of a lack of competitive markets on technical change and therefore do not agree on public policies that directly or indirectly impact on market structure. It may be the case that bigness and fewness promote technical change by overcoming some of the other generally recognized market failures. In that case, movements away from competitive markets may be encouraged on the grounds of promoting technical change. (Other policy controls could be implemented to avoid other problems associated with less than perfectly competitive markets.) The verdict with respect to this market failure and public policies in response to that failure awaits future conceptual and empirical research.

Externalities refer to costs or benefits that result from the production and/or use of a good or service and which are incurred by individuals or firms that are not directly involved in the economic transaction regarding that good or service. Externalities occur because of ill-defined property rights. An example of an external cost is air pollution that results from a manufacturing process and is incurred by individuals that in no way use or benefit from the product being made. An example of an external benefit is when a process innovation of one firm helps another firm reduce its costs. When externalities exist, the price of the good or service does not reflect its true benefits and costs. Government intervention is sometimes suggested to correct the prices of the goods or services to reflect the externalities and to impose costs and benefits on the appropriate parties.

With respect to technological innovations, the externality of most concern is the developing firm's or the inventor's property rights to the innovation. If other firms can easily copy or directly use the innovation, an externality will exist, and the innovator will have less incentive to conduct research and development. Potential inventors are reluctant to invest heavily in research when they cannot reap the full rewards of their efforts. Specific public policy instruments to address problems of externalities are discussed in the following subsection.

The third market failure of concern, failures with respect to information and uncertainty, is present to some extent in all markets. These types of failures are quite complicated. The basic argument is, however, that all producers and consumers must either have perfect information or, in the cases where perfect information does not exist, all producers and consumers must be able to insure against the risk associated with the lack of certain information. The failure to meet this condition is sometimes referred to as a lack of contingent claims markets.

In the case of technological innovations, it is obvious that perfect information does not exist. In the cases of some technological advances --for example, evolutionary developments in a particular technology or a straightforward application of an existing technology to a new application--the uncertainties are small and groups of individuals and sometimes firms can, in effect, jointly insure themselves against the risk that development and/or diffusion of the new technology will not be successful. However, in other cases the 
uncertainties of technological developments are so great or the potential payoffs from the new technologies are so uncertain that individuals and firms cannot insure themselves against the risks. Also, inherent uncertainties are not evident ex-ante in all cases. In the cases where the risks are great and the potential payoffs are large and far in the future, arguments can be made that the public sector should directly or indirectly subsidize the R\&D.

\subsection{PUBLIC POLICY RESPONSES TO MARKET FAILURES}

The market failures that lead to the private sector's suboptimal research and development efforts and therefore to less than socially optimal levels of technical change can be made less severe by government intervention. In this section we discuss various direct and indirect public policy instruments that can be used to correct the market failures or compensate for the negative effects of the market failures. By indirect policy instruments we mean those public sector measures that alter the incentive" structurfe of the private sector with respect to technical change such that the pursuit of invention, innovation, and diffusion is made more attractive, By direct policy instruments we mean the direct involvement of the public sector in one or more of the three stages of technical change--invention, innovation, and diffusion.

\subsubsection{Indirect Intervention}

Several types of policy instruments have been suggested by economists to address the three market failures discussed in the previous section. Below we discuss six specific indirect instruments that have. been advocated and to some extent implemented by the U.S. in an attempt to foster technical change. ${ }^{13}$

\subsubsection{Antitrust Policies}

Although the Schumpeter hypothesis remains unproven when viewed from the perspective of the entire economics discipline, there are researchers that argue that the hypothesis is true or false. In reality, the Schumpeterian hypothesis may or may not hold depending on the type of innovation and the type of market being considered. If the hypothesis is accepted as true, an obvious policy implication is that strong antitrust policies--i.e., policies that promote industries with firms of smaller size and less market power--are not particularly good if rapid technical change is a goal. To foster technical change, some antitrust rules might be made less severe, or at minimum firms might be encouraged to collaborate in the area of technical change--e.g., joint ventures. Such collaboration could also occur through, for example, trade organizations or through multifirm centers set up to develop and jointly utilize new technologies. This type of interfirm interaction is now receiving more consideration as U.S. regulators are following the leads of countries such as Japan.

\footnotetext{
${ }^{13}$ For details on the U.S.'s efforts to promote technical change, see Moore (1988).
} 
If the Schumpeter hypothesis is, however, false, the obvious implication is that smaller firms and more competition should be encouraged. For example, some argue that monopolists may delay the commercialization of their inventive activities because they do not want to affect the profits from their current product. Bittlingmayer (1988) argues that if competitors are allowed to cross-license or enter pooling agreements, the patents on their common products can lead to powers enjoyed by classic cartels. The firms could specify price or royalty terms that replicate the effects of price-fixing agreements.

\subsubsection{Patents}

The inability of firms and individuals to protect the rewards of innovative activities from competitors can severely limit the overall incentives of R\&D. The commonly used measure to protect property rights of inventors is the patent. Patents protect a new technology--one judged to be of a kind that can be used to produce a substantially improved product or process--by conferring a monopoly right for a limited time to the inventor. Although the optimal length of patents is a subject of continuing debate [see Tandon (1982)], the current length of patents in the U.S. is seventeen years. In other countries, for example the United Kingdom, the length can be as long as twenty years. ${ }^{14}$

The patent system as a means to protect property rights has been and continues to be the subject of debate. Patents are generally recognized as a means to guarantee a return to the inventor for his research efforts, and some [see, for example, Scherer (1980)] argue that the patent system encourages the disclosure of information about the new technology. There are, however, costs associated with patents, and arguments exist about the extent of their net benefits. From a social welfare perspective, the maximum benefits of a new technology are realized when information about that technology is available free of charge. However, the patenting system works opposite to this condition. The basic argument is that patents will encourage inventive activity, but may restrict the diffusion of that activity. Economists suggest that a limited-period patent is the best response to this problem, but, as stated above, argue about the appropriate length of patent protection.

Stoneman (1983) argues that "The conflict between encouraging invention and discouraging diffusion is perhaps best considered at an empirical level." Two relevant questions are posed. "First, has the patent system worked effectively as an incentive to invention? Second, has the existence of property rights in invention significantly affected the spread of new technology?" Stoneman reviews the relevant literature and suggests that the empirical evidence shows that patents possibly play only a minor role in stimulating invention and in most cases do not prevent imitation. Patents may not, therefore, slow down diffusion to any great extent. Stoneman goes on to argue that

\footnotetext{
${ }^{14}$ Some have argued that patents accomplish their purpose only if used in combination with sound antitrust policy. Many firms, for example, patent products just to keep their rivals from inventing earlier. Such products are often never commercialized. For evaluation of effectiveness of patents see Judd (1985) and Kamien and Tauman (1986).
} 
monopoly power in the hands of the inventor can or will slow down the use of new technologies to some degree.

Other economists have noted that other mechanisms exist for inventors to protect their innovations. For example, Arrow (1962) suggests that secrecy is an alternative way to maintain property rights to an invention, as may be brand loyalty, or other significant entry barriers. Mcgee (1968) suggests that patents may provide relatively too much of some kinds of research, and too little of others. Since not all discovery is patentable, the law may tend to bias search toward areas that are favored by it.

The consensus opinion about patents would appear to be that patents perform an essential function; but our current failure to adequately measure their performance and to monitor the incentives of the patent holders makes them a less than perfect instrument to protect inventive and intellectual property rights.

\subsubsection{Standardization}

Recall that the third type of market failure mentioned in the above subsection had to do with the lack of information about new technologies and the risk that lack of information imposes on firms. The uncertainties are usually divided into two categories-technological and market. Government regulations to promote standardization of products and processes has been suggested to help reduce technological uncertainty by increasing the likelihood that a new technology will mesh with other existing technologies. It is argued that standardization, if left to a firm or group of firms, can be misused by making standards too complex for rivals to maintain. Essentially, complex standards can create unfair barriers to entry and result in problems associated with non-competitive markets.

\subsubsection{Provision of Information}

Consumers are often apprehensive about new technologies, resulting in market uncertainties. Government provision of information about new technologies is often called for, especially in cases where positive externalities may result from the diffusion of the technology. The government's activities in promoting energy conservation technologies--where positive externalities may exist from reducing oil consumption--are an example. Further, if information is of a non-proprietary type, it may be more efficient for the government to disseminate it. Another example is the activities carried out by the National Institute of Standards and Technology (NISI'). The testing of inventions, such as those conducted at NIST and the national labs, provide information about the technical aspects of new technologies and may be all that is needed to gain acceptance by the public."

${ }^{15}$ Producers in the innovation process face a different set of uncertainties such as risks associated with rival inventions and uncertainty about success in-research. 
The public sector may also play an important role in providing information that reduces market uncertainties. Summary market information provided by government agencies such as the Department of Commerce and the Department of Energy and by national laboratories may only be available from public records: Provision of such information by the private may not be possible because the data on which the summary statistics are based are often proprietary and thus would be difficult or impossible to collect by an outside organization.

\subsubsection{Government Procurement}

The public sector can also decrease the market uncertainties associated with a new technology by insuring a buyer for the technology or the product or service from the technology. It has been shown that the ability of the government to influence the innovative process is inversely related to the number of potential buyers of the new technology. It has also been shown empirically that government procurement policies have led to breakthroughs in certain new technologies such as the computer and aircraft industries. [See, for example, Dorfman (1987) and Gansler (1984)].

\subsubsection{Taxes and Subsidies}

Taxes and subsidies can be used as a means to reduce externalities by forcing freeriders (firms or individuals that benefit from a new technology without paying the inventor for the privilege to use the technology) to pay for external benefits. Alternatively, taxes and subsidies can be used as a method to override the effects of market failures, rather than correcting them. The government can provide general incentives to industry to increase their inventive activities through, for example, tax credits on R\&D efforts. Or government can provide subsidies to specific firms to develop/adopt specific technologies. Such projects include R\&D that would not otherwise be carried out by private firms due to their risky nature, high capital requirements, or long gestation periods; or they may be projects of great national or strategic importance. A problem with such sponsorship is that the public sector cannot determine the extent of benefits or spillovers to the contractor and is unable to charge for such benefits. Additionally, the government cannot monitor the intensity of research effort.

Government can also award diffusion grants to inventors. Such grants could provide the resources that inventors need to launch their inventions. Adoption grants to potential consumers are another way by which new products with high adoption costs can be easily adopted. For example, if a new technology involves the switch from labor intensive production techniques to capital intensive ones, high initial capital requirements may delay adoption.

An example of a current government program to promote selected technologies is the U.S. Department of Energy's Energy Related Inventions Program (ERIP). That program supports the development and transfer of selected new energy technologies and thus helps to overcome market failures associated with externalities and with information

and uncertainty. It can be argued, in fact, that the public-sector recognition given to the new technologies is as valuable as direct government funding. The government's adoption 
of a technology effort signals to the private sector the public sector's belief that the new technology has technical and/or commercial merit. That provision of information may in turn promote private-sector financial support.

\subsubsection{Direct Intervention}

An alternative to the government eliminating or counteracting market failures that hinder the private sector's inventive activities is to have the public sector participate directly in technical change. Participation can occur at the inventive, innovative, and/or diffusion steps.

Various reasons may exist for direct government involvement. For example, it is often difficult for government to identify potential inventors that could conduct R\&D of certain types. In addition, the lack of a means to adequately monitor the research process creates what economists call a "principal-agent" problem. The government, as the principal, is unable to monitor the activities of its agent--the contractor. On the one hand, there are measurement problems dealing with appropriability and the value of R\&D activities. On the other hand, there is a lack of an adequate measure of success in innovation. For example, in most cases there may be only one firm that is able to successfully invent a new technology, but those who fail to achieve the invention may still have improved their ability to pursue subsequent research projects. The quantification of such gains is difficult, if not impossible. Thus, the inability to monitor the agent's behavior leads to one argument for direct government involvement in technological change.

Further, in the case of long-term, high-risk R\&D the public sector may hold a relative advantage because of the continuity of effort and economies of scale. In addition, there is an obvious role for government to play in the research, development, and use of innovations that are public goods, such as military technologies. In this subsection we review the ways the public sector can be directly involved in technological change. We also explore the various ways and points at which an interface between the public and private sectors can occur.

\subsubsection{Points at which the Public-Private Interface Can Occur}

Figure 1 summarizes the various points at which the public and private sectors can interface in the process of technical change. The three steps in technical change are given--invention, innovation, and diffusion--along with three general avenues of technical change--public sector, private sector, and public-private sector joint ventures. Note that there are several nodes at which this interface or transfer of ideas and technologies can occur--ranging from an interface at the invention step through joint ventures to an interface at the diffusion step. At one extreme the government may simply be involved in the generation of ideas--through public-sector invention at, for example, national laboratories or through joint ventures with private firms--and then transfer those ideas to the private sector for the innovative and diffusion step. At the other extreme the government may through joint ventures or on its own be involved in the inventive, 


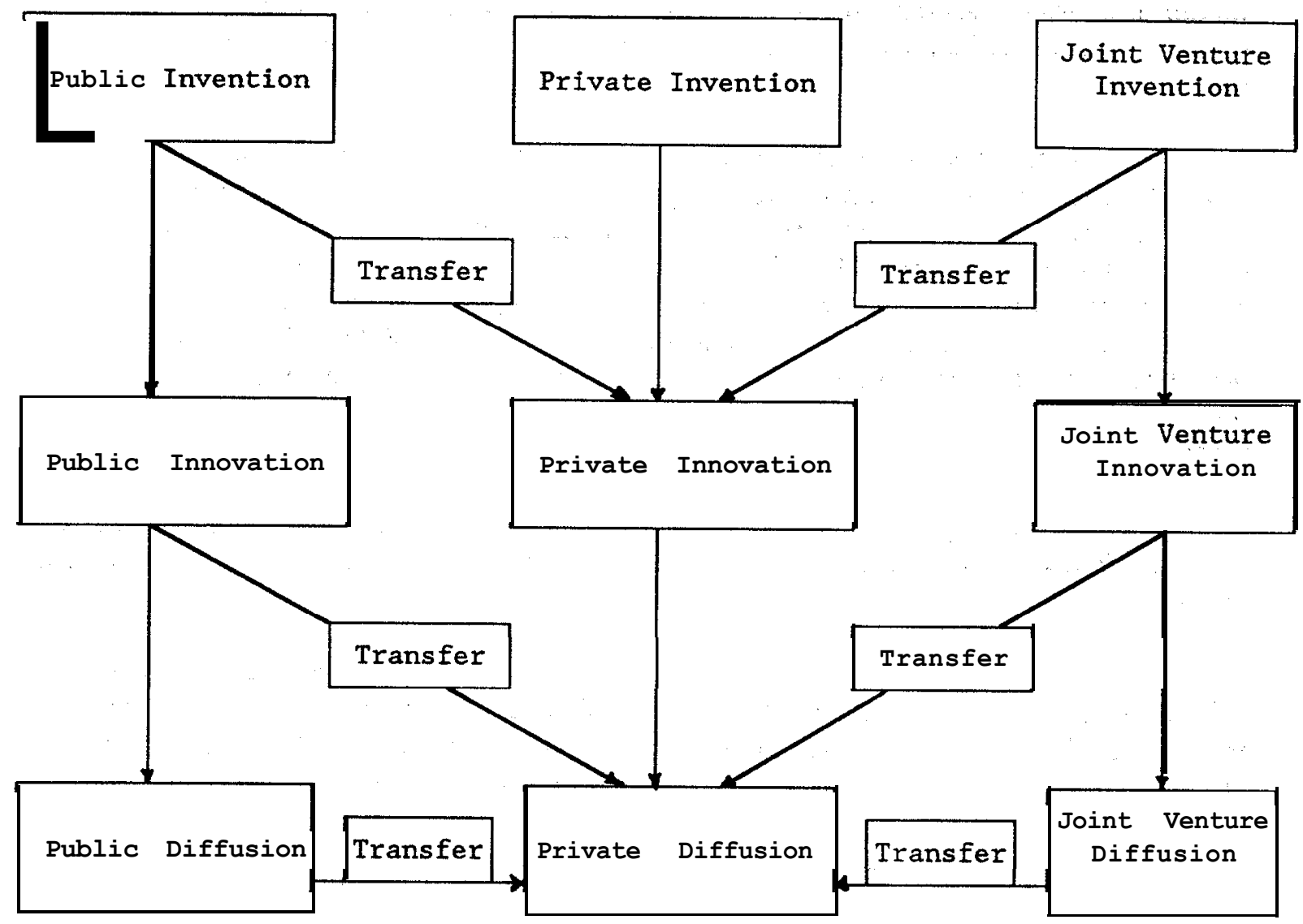

Fig. 1. Points at which the public-private interface can occur 
innovative, and diffusion steps. Transfer to the private sector may, in fact, never occur in this latter extreme.

Several questions present themselves when the public-private interface is viewed as in Fig. 1. For example, can we say anything about what types of technologies are best transferred at different points? What transfer mechanisms work best at different transfer points and for different types of technologies? What policy options are available at the different potential transfer points? Is there any way to measure the effectiveness of transferring technologies at different points? How much government involvement is optimal?

For the most part, the economics discipline has not addressed questions at this level of disaggregation. As discussed in previous sections of this report, the economics profession has focused on the big picture and paid little attention to prescribing how a public-private interface should be structured given a particular technology and particular market conditions.

In the following subsection we present some general comments with respect to the direct involvement of the public sector in the innovative process., While the current literature is limited, a review of that literature suggests potential relationships and fruitful avenues for future research.

\subsubsection{Public-Private Sector Joint Ventures}

An interface can be set up between the public and private sectors at any of the three technical change stages. Economists have argued that the advantages of jointventure $R \& D$ include the ability to pool resources, while the major drawbacks are in reaching some kind of an agreement on sharing post-invention rewards and identification of compatible potential partners.

Although much of the work by economists in the area of joint ventures has concerned joint ventures among private firms, some of that research is suggestive of public-private sector joint ventures. Jacquemin (1988) suggests several benefits of joint ventures. Those benefits include the following: (1) Cooperative agreements are an alternative to either pure market transactions or integration within a firm under a centralized administrative structure. In-house development or mergers are said to create inflexible structures without easy means for switching research capability, strategy, and partners over time. Further, arm's-length transactions do not allow for long-term relationships, which are generally crucial in technology, (2) The second advantage of cooperative $R \& D$ is to increase the speed of invention and innovation with diminished risk of failure; and (3) The pooling of various complementary resources in R\&D can provide financial capital at better conditions, spread the fixed and generally sunk costs of technology development, and produce synergistic effects by the combination of research information, teams of scientists, technical and marketing know how, and so forth. Jacquemin lists the drawbacks of joint ventures as (1) the difficulty involved in selecting partners and the possibility of defining contributions by the participants, and (2) the difficulty in managing joint ventures and, sharing the benefits of those ventures. 
The main argument in favor of encouraging joint ventures concerns the difficulty in appropriating the returns to inventive activities. ${ }^{16}$ Joint venture $R \& D$ can be seen as a way to simultaneously internalize the externalities caused by significant R\&D spillovers, hence improving the incentives and limiting wasteful duplication. The joint venture is also argued to provide more efficient sharing of information between the public and private sectors and among private sector firms. Katz (1986) has argued unambiguously that cooperative $\mathrm{R} \& \mathrm{D}$ increases both $\mathrm{R} \& \mathrm{D}$ and production with respect to the non-cooperative solution. ${ }^{17}$

\subsubsection{Public Sector Invention. Innovation, and Diffusion}

The government can directly engage in invention, innovation, and diffusion by setting up research facilities such as the national laboratories or by sponsoring activities at public sector facilities such as the Tennessee Valley Authority. Benefits of these activities include the ability of government to fund ambitious and unique (e.g., in the sense of special defense needs) research projects and the capability to bear adverse consequences of uncertain research. Additionally, government is most suited to invest in generic research because generic knowledge is usually nonproprietary. Government can aid in development by validating and testing technologies invented by private inventors at its laboratories. Government assistance in diffusion can come in the form of marketing through government facilities, e.g., the National Energy Software Center. A single government unit may engage in all three stages of the innovative process.

The drawbacks of independent government research activities include possible inefficiencies due to the lack of market pressures and due to bureaucratic "red tape." Nelson (1987) also argues that due to the absence of perfect information, government participation in $\mathrm{R} \& \mathrm{D}$ may replace or duplicate private research efforts. Empirical evidence on this issue remains elusive, as do conclusions regarding the impact of government $\mathrm{R} \& \mathrm{D}$ on private-sector inventive efforts. ${ }^{18}$ One reason for the lack of research on direct government participation in $R \& D$ is that the government often invests in defense-related R\&D whose findings are seldom made public.

${ }^{16}$ Economists have devoted considerable efforts to. the problem of non-appropriability of R\&D gains. See, for example, Dasgupta (1987) for a literature survey. Also see, Dasgupta and Stoneman (1987).

${ }^{17}$ For more on research joint-ventures, see Grossman and Shapiro (1985).

${ }^{18}$ See, for example, Lichtenberg (1987) for more details. 


\section{CONCLUSIONS}

The role of the federal government in the innovative process remains the subject of significant debate among economists. Although most economists would agree that some role must be played by the public sector, our current conceptual and empirical knowledge is lacking. Little consensus has thus been reached about how the government should respond to the problem in general, and even less consensus exists about how particular technologies in particular markets should be dealt with. Dasgupta (1987) states that "The economics of technology policy is in its infancy.... It is widely appreciated today that R\&D investment has a strong influence on an economy's performance. It is also appreciated that information, the output of R\&D, possesses exceptional characteristics. Furthermore, we have seen that $R \& D$ technologies possess features which make the activity of information production particularly problematic. And yet the massive recent literature on public economics has barely touched upon these matters. The microeconomic theory of technology policy...is somewhat of a stepchild of our profession."

This paper has presented a general overview of the economics literature on technological change and focused particularly on the interface that exists between the public and private sectors in promoting the transfer and diffusion of new technologies. The paper has suggested that the public sector can encourage the process of innovation by either directly participating in the process of technical change or by indirectly stimulating the private sector's innovative activities. And although both methods have been shown to promote technical change, economists have not yet been able to develop a generally agreed upon formula that dictates what method is most appropriate in any given case. Nelson's (1987) views on public sector participation in the R\&D process may best summarize the state of the economics literature with regard to the question of public

involvement: "One can see the task of institutional design as somehow to get the best of both worlds. Establish and preserve property rights, at least to some degree, where profit incentives are effective in stimulating action, and where the costs of keeping knowledge private are not high. Share knowledge where it is efficient to do so, and the cost in terms of diminished incentives is small. Do the work cooperatively, or fund it publicly, and make public those aspects of technology where the advantages of open access are greatest, or where proprietary claims are difficult to police."

It is likely that the arguments by economist with respect to the government's role in technological change will become more definitive as more detailed conceptual and empirical studies are undertaken. It is unlikely, however, due to the number of dynamic factors that are known to influence the innovative process, that the economics profession will develop a formula or set of formulae for technical change or the involvement of the public sector in that change. A movement toward interdisciplinary research, which is currently underway, is the most promising avenue for studying the role of public policy in promoting technical change. 


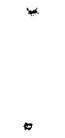




\section{REFERENCES}

Angelmar, R., "Market Structure and Research Intensity in High-TechnologicalOpportunity Industries," Journal of Industrial Economics, 34, 69-79. 1985.

Arrow, K. J., "The Economic Implications of Learning By Doing," Review of Economic Studies, 155-73, 1962.

Barrel, Yoram, "Optimal Timing of Innovations," Review of Economics and Statistics, 50, 348-55, 1968.

Bittlingmeyer, G., "Property Rights, Progress, and the Aircraft Patent Agreement," Journal of Law and Economics, 31, 22748, 1988.

Comanor, W. S. and F. M. Scherer, "Patent Statistics as a Measure of Technical Change," Journal of Political Economy, 57, 392-98, 1969.

Dasgupta, Partha and Joseph Stiglitz, "Industrial Structure and the Nature of Innovative Activity,” Economic Journal, 358, 26693, June 1980a.

Dasgupta, P. S. and J. E. Stiglitz, "Uncertainty, Industrial Structure and the Speed of R\&D," Bell Journal of Economics, 11, 1-28, 1980 .

Dasgupta, P. and P. Stoneman, Economic Policy and Technological Performance, Cambridge University Press, Cambridge, MA, 1987.

Dasgupta, P., "The Economic Theory of Technology Policy: An Introduction,” Economic Policy and Technological Performance, eds., P. Dasgupta and P. Stoneman, Cambridge University Press, Cambridge, MA., 1987.

Dorfman, N. S., Innovation and Market Structure: Lessons from the Computer and Semiconductor Industries, Ballinger Publishing Co., Cambridge, MA, 1987.

Easingwood, C. J., "Product Lifecycle Patterns for New Industrial Products," $\underline{\text { R\&D }}$ Management, 18(1), 23-32, 1988.

Futia, Carl A, "Schumpeterian Competition," Quarterlv Journal of Economics, 94(4), 67595, June 1980

Gansler, J. S., The Defense Industry, MIT Press, Cambridge, 1984.

Goel, R. K., "Market Structure, Innovations, and Welfare," unpublished dissertation, University of Houston, 1987. 
Griliches, Z., "Hybrid Corn: An Exploration in the Economics of Technological Change," Econometrica, 25(4), 501-22, 1957.

Griliches, Z., A. Pakes and B. H. Hall, "The Value of Patents as Indicators of Inventive Activity," Economic Policy and Technological Performance, Eds.,P. Dasgupta and P. Stoneman, Cambridge University Press, Cambridge, MA, 1987.

Grossman, G. M. and C. Shapiro, "Research Joint Ventures: An Antitrust Analysis," working paper, Woodrow Wilson School of Public and International Affairs, 1985.

Hall, B. H., Z. Griliches, and J. A. Hausman, "Patents and R\&D: Is There a Lag?" International Economic Review, 27, 265-83, 1986.

Hannan, T. H. and J. M. McDowell, "Rival Precedence and the Dynamics of Technology Adoption," Economica, 54, 155-71, 1987.

Hirshleifer, J., Price Theorv and Applications, Prentice-Hall, New York, 1982.

Jacquemin, A, "Cooperative Agreements in R\&D and European Antitrust Policy," European Economic Review, 32, 551-560, 1988.

Jensen, R., "Adoption and Diffusion of an Innovation Under Uncertainty," Journal of Economic Theory, 27, 182-93, 1982.

Judd, Kenneth L., "On the Performance of Patents," Econometrica. 53(3), 567-85, May 1985.

Kamien, M. I. and N. L. Schwartz, "Patent Life and R\&D Rivalry," American Economic Review, 64, 183-87, 1974.

Kamien, M. I. and N. L. Schwartz, "Market Structure and Innovation: A Survey," Journal of Economic Literature, 13, 1-37, 1975.

Kamien, M. I. and N. L. Schwartz, "On the Degree of Rivalry for Maximum Innovative Activity," Quarterlv Journal of Economics, 90, 245-60, 1976.

Kamien, M. I. and N. L. Schwartz, Market Structure and Innovation. Cambridge University Press, Cambridge, MA, 1982.

Kamien, M. I. and Y. Tauman, "Fees Versus Royalties and the Present Value of a Patent," Quarterlv Journal of Economics, 100, 471-91, 1986.

Katz, M. L., "An Analysis of Cooperative Research and Development," Rand Journal of Economics, 17, 527-43, Winter 1986.

Lee, T. and L. L. Wilde, "Market Structure and Innovation: A Reformulation," Quarterly Journal of Economics, 94, 429-36, 1980. 
Levin, Richard C., "Technical Change, Barriers to Entry, and Market Structure," Economica, 45, 347-61, November 1978.

Levin, R. C. and P. C. Reiss, "Tests of a Schumpeterian Model of R\&D and Market Structure," R\&D. Patents and Productivity, Z. Griliches, ed., University of Chicago Press, Chicago, Illinois, 1984.

Lichtenberg, F. R., “The Effect of Government Funding on Private Industrial Research and Development: A Re-Assessment," Journal of Industrial Economics. 36, 97-104, 1987.

Loury, G. C., "Market Structure and Innovation," Quarterlv Journal of Economics, 93, 395410, 1979.

Lucas Jr., R. E., “Tests of a Capital Theoretic Model of Technical Change," Review of Economic Studies, 34, 175-90, 1967.

Lunn, J., "An Empirical Analysis of Process and Product Patenting: A Simultaneous Equation Framework," Journal of Industrial Economics. 34, 319-30, 1986.

Mansfield, Edwin, Industrial Research and Technological Innovation, W. W. Norton, New York, 1968.

Mansfield, E., "Composition of R\&D Expenditures: Relationship to Size of Firm, Concentration, and Innovative Output," Review of Economics and Statistics. 63, 61015, 1981.

Mcgee, J. S., "Patent Exploitation: Some Economic and Legal Problems," and Economics, 135-62, 1968.

Moore, J. H., "Knowledge Transfers in the United States," European Economic Review, 32, 591-603, 1988.

National Science Foundation, The Process of Technological Innovation: Reviewing the Literature, Government Printing Office, Washington, D.C., 1983.

Nelson, R. R. and S. G. Winter, "Forces Generating and Limiting Competition under Schumpeterian Composition," Bell Journal of Economics, 9, 524-48, 1978.

Nelson, R. R. and S. G. Winter, An Evolutionarv Theory of Economic Change, Belknap Press, Cambridge, MA, 1982.

Nelson, R. R., Understanding Technical Change as an Evolutionarv Process, NorthHolland, New York, 1987. 
Rasmussen, J. A, "Applications of a Model of Endogenous Technical Change to U.S. Industry Data," Review of Economic Studies, 40, 225-38, 1973.

Reinganum, Jennifer F., "On the Diffusion of New Technology: A Game Theoretic Approach,” Review of Economic Studies, 48(3), 395-405, July 1981.

Reinganum, Jennifer F., "Market Structure and the Diffusion of New Technology" Bell Journal of Economics, 12(2), 618-24, Autumn 1981.

Reinganum, J. F., "Innovation and Industry Evolution," Quarterlv Journal of Economics, 99, 81-99, 1985.

Rosenberg, Nathan, Perspectives on Technology' Cambridge University Press, Cambridge, 1976.

Scherer, F. M., Industrial Market Structure and Economic Performance, second edition, Houghton Mifflin Co., Boston, MA., 1980.

Scherer, F. M., Innovation and Growth: Schumneterian Perspectives, The MIT Press, Cambridge, MA' 1984.

Schumpeter, J. A, Capitalism, Socialism. and Democracy, Harper \& Brothers Publishers, New York, 1947.

Stiglitz, J. E., Economics of the Public Sector, second edition, W. W. Norton, New York, 1988.

Stoneman, P., The Economic Analysis of Technological Change, Oxford University Press, 1983.

Stoneman, P., "Technological Diffusion: The Viewpoint of Economic Theory," Ricerche Economiche, XL, 4, 585-606, 1986.

Tandon, Pankaj, "Optimal Patents with Compulsory Licensing," Journal of Political Economy, 3, 47086, June 1982.

Tandon, Pankaj, "Innovation, Market Structure, and Welfare," American Economic Review. 74(3), 394-403, June 1984. 


\section{SELECTED BIBLIOGRAPHY}

\section{DIFFUSION}

Akinola, Amos A, "Dynamic Innovator-Imitator (IN-IM) Diffusion Model," Canadian Journal of Agricultural Economics, 34(1), 113-24, March 1986.

Allen, Beth, "Some Stochastic Processes of Interdependent Demand and Technological Diffusion of an Innovation Exhibiting Externalities Among Adopters," International Economic Review, 23(3), 595-608, October 1982.

Antonelli, Cristiano, "The Diffusion of an Organizational Innovation: International Data Telecommunications and Multinational Industrial Firms," International Journal of Industrial Organization, 3(1), 109-18, 1985.

Bass, Frank M., "The Relationship between Diffusion Rates, Experience Curves, and Demand Elasticities for Consumer Durable Technological Innovations," Journal of Business, Part 2, 53(3), 851-67, July 1980.

Benoit, Jean-Pierre, "Innovation and Imitation in a Duopoly," Review of Economic Studies, 52(1), 99-106, January 1985.

Benvignati, Anita M., 'The Relationship Between the Origin and Diffusion of Industrial Innovation," Economica, 49(195) 313-23, August 1982.

Burstein, M. L., "Diffusion of Knowledge-based Products: Applications to Developing Economies"' Economic Inquiry, 22(4), 612-33, October 1984.

Cameron, Rondo, "The Diffusion of Technology as a Problem in Economic History," Economic Geography, 51(3), 217-30, July 1975.

Cosmas, Stephen C. and Jagdish N. Sheth, "Identification of Opinion Leaders Across Cultures: An Assessment for Use in the Diffusion of Innovations and Ideas," Journal of International Business Studies, 11(1), 66-73, Spring/Summer 1980.

Dahlman, Carl and Larry Westphal, "The Transfer of Technology," Einance and Development, 4, 6-9, December 1983.

Easingwood, C. J., "Product Lifecycle Patterns for New Industrial Products" R\&D Management. 18(1), 23-32, 1988.

Feder, Gershon and Gerald T. O'Mara, "On Information and Innovation Diffusion: A Bayesian Approach"” American Journal of Agricultural Economics, 64(1), 145-47, February 1982. 
Feder, Gershon and Roger Slade, "The Acquisition of Information and the Adoption of New Technology," American Journal of Agricultural Economics, 66(3), 312-20, August 1984.

Feder, Gershon and Roger Slade, "The Role of Public Policy on the Diffusion of Improved Agricultural Technology," American Journal of Agricultural Economics, 67(2), 423-28, May 1985.

Feenstra, Robert C. and Kenneth L. Judd, "Tariffs, Technology Transfer, and Welfare," Journal of Political Economy, 6, 1142-65, December 1982.

Fudenberg, D. and J. Tirole, "Preemption and Rent Equalization in the Adoption of New Technology," Review of Economic Studies, 52, 383-401, 1985.

Globerman, Steven, "The Adoption of Computer Technology in Hospitals," Journal of Behavioral Economics, 11(2), 67-95, Winter 1982.

Gold, Bela, "Technological Diffusion in Industry: Research Needs and Shortcomings," Journal of Industrial Economics, 29(3), 247-69, March 1981.

Gort, Michael and Akira Konakayama, "A Model of Diffusion in the Production of an Innovation,” American Economic Review, 72(5), 111 1-20, December 1982.

Gort, Michael and Steven Klepper, "Time Paths in the Diffusion of Product Innovations", Economic Journal, 92(367), 630-53, September 1982.

Gritiches, Z., "Hybrid Corn: An Exploration in the Economics of Technological Change", Econometrica, 25(4), 501-22, 1957.

Hannan, T. H. and J. M. McDowell, "Rival Precedence and the Dynamics of Technology Adoption"” Economica, 54, 155-71, 1987.

Hayami, Yjiro, "Conditions for the diffusion of Agricultural Technology: An Asisan Perspective,” Journal of Economic History, 34(1), 131-48, March 1974.

Hernes, Gudmund, "Diffusion and Growth-The Non-homogeneous Case," Scandinavian Journal of Economics, 78(3), 427-36, 1976.

Hirschey, Robert C. and Richard E. Caves, "Research and Transfer of Technology by Multinational Enterprises, Oxford Bulletin of Economics and Statistics, 43(2), 11530, May 1981.

Ireland, N. and P. Stoneman, "Technological Diffusion, Expectations and Welfare," Oxford Economic Papers, 38(2), 283-304, July 1986. 
Jeannet, Jean-Pierre and Bertil Liander, "Some Patterns, in the Transfer of Technology within Multinational Corporations," Journal of International Business Studies, 9(3), 108-18, Winter 1978.

Jensen, R., "Adoption and Diffusion of an Innovation Under Uncertainty," Journal of Economic Theory, 27, 182-93, 1982.

Jensen, Richard, "Innovation Adoption and Diffusion When There Are Competing Innovations," Journal of Economic Theorv, 29(1), 161-71, February 1983.

Katz, Michael L and Carl Shapiro, "Technology Adoption in the Presence of Network Externalities," Journal of Political Economy 94(4), 822-41, August 1986.

Krugman, Paul, "A Model of Innovation, Technology Transfer, and the World Distribution of Income," Journal of Political Economy, 87(2), 253-66, April 1979.

Lekvall, Per and Clas Wahlbin, "A Study of Some Assumptions Underlying Innovation Diffusion Functions," Swedish Journal of Economics, 75(4), 362-77, December 1973.

Levy, Garboua, Louis, "Innovations et Diffusion Des Produits De Consommation (Innovations and the Diffusion of Consumer Goods. With English summary.), Economie Appliquee, 39(3), 521-82, 1987.

Mansfield, Edwin, Industrial Research and Technological Innovation, W. W. Norton, New York, 1968.

Mansfield, Edwin, "Industrial Research and Development: Characteristics, Costs, and Diffusion of Results," American Economic Review, 59(2), 65-71, May 1969.

Mansfield, Edwin and Anthony Romeo, "Technology Transfer to Overseas Subsidiaries by U.S.-Based Firms," Quarterlv Journal of Economics, 95(4), 737-50, December 1980.

McCombie, J. S. L., "How Important is the Spatial Diffusion of Innovations in Explaining Regional Growth Rate Disparities?" Urban Studies, 19(4), 377-82, November 1982.

Meir, Avinoam, "Innovation Diffusion and Regional Economic Development: The Spatial Diffusion of Automobiles in Ohio," Regional Studies, 15(2), 111-22, 1981.

Moore, J. H., "Knowledge Transfers in the United States," European Economic Review, 32, 591-603, 1988.

Morrill, Richard L. and Diane Manninen, "Critical Parameters of Spatial Diffusion Process,” Economic Geography, 51(3), 269-77, July 1975.

Nekhoroshev, Iu. S., "Scientific and Production Experience and the Mechanism of Its Diffusion," Problems of Economics, 23(2), 35-45, June 1980. 
Oster, Sharon M. and John M. Quigley, "Regulatory 'Barriers to the Diffusion of Innovation: Some Evidence from Building Codes,' Bell Journal of Economics, 8(2), 361-77, Autumn 1977.

Quirmbach, Herman C., "The Diffusion of New Technology and the Market for an Innovation," Rand Journal of Economics, 17(1), 33-47, Spring 1986.

Ray, G. F., "The Diffusion of New Technology: A Study of Ten Processes in Nine Industries" National Institute Economic Review, 48, 40-83, May 1969.

Reinganum, Jennifer F., "On the Diffusion of New Technology: A Game Theoretic Approach" Review of Economic Studies, 48(3), 395-405, July 1981.

Reinganum, Jennifer F., "Market Structure and the Diffusion of New Technology," Bell Journal of Economics, 12(2), 618-24, Autumn 1981.

Roffe, P., "International Code of Conduct on Transfer of Technology," Journal of World Trade Law, 11(2), 186-91, March-April 1977.

Rosenberg, Nathan, "Factors Affecting the Diffusion of Technology," Explorations in Economic History, 1. 3-33, Fall 1972.

Rosenberg, Nathan, Perspectives on Technology, Cambridge University Press, Cambridge, 1976.

Rosegger, Gerhard, "Diffusion and Technological Specificity: The Case of Continuous Casting," Journal of Industrial Economics, 28(1), 39-53, September 1979.

Shen, T. Y., “Technology Diffusion, Substitution, and X-Efficiency,” Econometrica, 41(2), 263-84, March 1973.

Sloan, Frank A, et al., "Diffusion of Surgical Technology: An Exploratory Study," Journal of Health Economics, 5(1), 31-61, March 1986.

Soete, Luc, "International Diffusion of Technology, Industrial Development and Technological Leapfrogging"” World Development, 13(3), 409-22, March 1985.

Soete, Luc and Roy Turner, "Technology Diffusion and the Rate of Technical Change," Economic Journal, 94(375), 612-23, September 1984.

Stoneman, P., "Intra-Firm Diffusion, Bayesian Learning and Profitability," Economic Journal, 91(362), 375-88, June 1981.

Stoneman, P., The Economic Analvsis of Technological Change, Oxford University Press, 1983. 
Stoneman, P., “Technological Diffusion: The Viewpoint of Economic Theory," Ricerche Economiche, XL, 4, 585-606, 1986.

Stoneman, P. and N. J. Ireland, "The Role of Supply Factors in the Diffusion of New Process Technology,” Economic Journal, Supplement 66-78, March 1983.

Stoner, Robert D., "Diffusion of Technological Innovations Among Privately Owned Electric Utilities: 1950-1975," in Issues in Public Utilitv Regulation: Proceedings of the Institute of Public Utilities Tenth Annual Conference. Harry M. Trebing, ed., MSU Public Utilities Papers, East Lansing, Michigan "State University, Graduate School of Business Administration, Division of Research, 291-303, 1979.

Swan, Philip L., "The International Diffusion of an Innovation," Journal of Industrial Economics, 22(1), 61-69, September 1973.

Thomas, Morgan D. and Richard B. LeHeron, "Perspectives on Technological Change and the Process of Diffusion in the Manufacturing Sector," Economic Geoeranhv, 51(3), 231-51, July 1975.

Wilton, Peter C. and Edgar A. Pessemier, "Forecasting the Ultimate Acceptance of an Innovation: The Effects of Information," Journal of Consumer Research, 8(2), 162 71, September 1981.

Wozniak, Gregory D., “The Adoption of Interrelated Innovations: A Human Capital Approach," Review of Economics and Statistics, 66(1), 70-79, February 1984. 
$=$ 


\section{EMPIRICAL ISSUES}

Amihud, Yakov, "A Note on the Measurement of Technological Progress and Experience in Production," American Journal of Agricultural Economics, 59(4), 728-30, November 1977.

Angelmar, R., "Market Structure and Research Intensity in High-TechnologicalOpportunity Industries," Journal of Industrial Economics, 34, 69-79. 1985.

Baltagi, B. H. and J. M. Griffin, "A General Index of Technical Change," Journal of Political Economy, forthcoming 1988.

Bollard, Alan, "Technology, Economic Change, and Small Firms," Llovds Bank Review, 147, 42-56, January 1983.

Bunich, Pave1 G., "Cost Accounting and Raising the Effectiveness of Scientific-Technical Progress," Problems of Economics, 7, 58-79, November 1977.

Calvo, Guillermo A and Stanislaw Wellisz, "Technology, Entrepreneurs, and Firm Size," Quarterlv Journal of Economics, 95(4), 663-77, December 1980.

Comanor, W. S., "Research and Competitive Product Differentiation in the Pharmaceutical Industry in the United States," Economica. 31, 372-84, 1964.

Comanor, W. S. and F. M. Scherer, "Patent Statistics as a Measure of Technical Change," Journal of Political Economy, 57, 392-98, 1969.

Craven, John, "Input-Output Analysis and Technical Change," Econometrica, 51(3), 58598, May 1983.

Fel'zenbaum, V., "Cost Accounting and the Socioeconomic Effect of New Technology," Problems of Economics, 25(2), 21-38, June 1982.

Griliches, Z., "R\&D and Productivity Slowdown," American Economic Review, 70, 34348, 1980.

Griliches, Z., A. Pakes and B. H. Hall, "The Value of Patents as Indicators of Inventive Activity," Economic Policy and Technological Performance, Eds.,P. Dasgupta and P. Stoneman, Cambridge University Press, Cambridge, MA' 1987.

Hall, B. H., Z. Griliches, and J. A Hausman, "Patents and R\&D: Is There a Lag?" International Economic Review, 27, 265-83, 1986.

Haltmaier, Jane, "Measuring Technical Change," Economic Journal, 94(376), 924-30, December 1984. 
Huffman, Wallace E. and John A. Miranowski, "An Economic Analysis of Expenditures on Agricultural, Experiment Station Research," American Journal of Agricultural Economics, 63(1), 104-18, February 1981.

Hulten, Charles R., "On the "Importance" of Productivity Change," American Economic Review, 69(1), 126-36, March 1979.

Kalt, Joseph P., "Technological Change and Factor Substitution in the United States: 1929-1967,' International Economic Review, 19(3), 761-75, October 1978.

Kay, Neil, "Technological Forecasting-A Note," Journal of Business, 2, 240-42, April 1977.

Kochanowski, Paul and Henry Hertzfeld, "Often Overlooked Factors in Measuring the Rate of Return to Government R \& D Expenditures," Policy Analvsis. 7(2), 153 67, Spring 1981.

Kopp, Raymond J. and V. Kerry Smith, "The Measurement on Non-neutral Technological Change," International Economic Review, 26(1), 135-59, February 1985.

Levin, R. C. and P. C. Reiss, "Tests of a Schumpeterian Model of R\&D and Market Structure," R\&D, Patents and Productivitv, Z. Griliches, ed., University of Chicago Press, Chicago, Illinois, 1984.

Link, Albert N., "An Analysis of the Composition of R\&D Spending," Southern Economic Journal, 49(2), 342-49, October 1982.

Luban, Florica and V. Dumitru, "On Some Models and Methods of Forecasting Technological Changes," Economic Computation and Economic Cvbemetics Studies and Research, 16(1), 59-65, 1982.

Lunn, J., "An Empirical Analysis of Process and Product Patenting: A Simultaneous Equation Framework"' Journal of Industrial Economics, 34, 319-30, 1986.

Mansfield, E., "Rates of Return from Industrial Research and Development," American Economic Association Proceedings, 55, 310-47, 1965.

Mansfield, Edwin, et al., "Social and Private Rates of Return from Industrial Innovations," Quarterlv Journal of Economics, 91(2), 221-40, May 1977.

Mansfield, Edwin, "Returns from Industrial Innovation," Technological Innovation: Government/Industry Cooperation, Arthur Gernstenfeld, ed., Assisted by Robert Brainard, New York: Chichester, England; Brisbane and Toronto: Wiley, Wileyinterscience, 16-19, 1979.

Mansfield, E., "Basic Research and Productivity Increase in Manufacturing," American Economic Review, 70, 263-72, 1980. 
Mansfield, E., "Composition of R\&D Expenditures: Relationship to Size of Firm, Concentration, and Innovative Output" Review of Economics and Statistics. 63, 61015, 1981.

Mansfield, Edwin, "Technological Change and Market Structure: An Empirical Study," American Economic Review, 73(2), 205-09, May 1983.

May, J. D., and M. Denny, "Factor-Augmenting Technical Progress and Productivity in U.S. Manufacturing”" International Economic Review, 3, 759-74, October 1979.

Mohnen, P. A, M. I. Nadiri and I. R. Prucha, "R\&D, Production Structure and Rates of Return in the U.S., Japanese and German Manufacturing Sectors: A Non-Separable Dynamic Factor Demand Model," European Economic Review, 30, 749-71, 1986.

Nelson, Richard R., "Research on Productivity Growth and Productivity Differences: Dead Ends and New Departures," Journal of Economic Literature, 19(3), 102964, September 1981.

Rasmussen, J. A, "Applications of a Model of Endogenous Technical Change to U.S. Industry Data," Review of Economic Studies, 40, 225-38, 1973.

Reid, Gavin C., "An Analysis of the Firm, Market Structure and Technical Progress," Scottish Journal of Political Economy, 26(1), 15-32, February 1979.

Sato, Ryuzo, and Takayuki Nono, “A Theory of Endogenous Technical Progress: Dynamic Bohm-Bawerk Effect and Optimal R \& D Policy," Zeitschrift fur Nationalokonomie. 42(1), 1-22, 1982.

Telser, Lester G., "Innovation: Its Public and Private Aspects and Some of Their Empirical Implications for Mergers," Economic Inquiry, 22(4), 334-59, October 1984.

Terleckyj, Nestor E., “What Do R\&D Numbers Tell Us About Technological Change?” American Economic Review' 2, 55-61, May 1980.

Zind, Richard G., "A Note on the Measurement of Technical Bias in the U.S. Economy," Review of Economics and Statistics. 61(2), 301-04, May 1979. 
$\dot{0}$

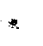




\section{PATENTS AND PUBLIC POLICY}

Barber, J. and G. White, "Current Policy Practice and Problems from a UK Perspective," Economic Policy and Technological Performance, eds., P. Dasgupta and P. Stoneman, Cambridge University Press, Cambridge, MA., 1987.

Beck, Roger L., "Patents, Property Rights, and Social Welfare: Search for a Restricted Optimum," Southern Economic Journal, 43(2), 1045-55, October 1976.

Bittlingmeyer, G., "Property Rights, Progress, and the Aircraft Patent Agreement," Journal of Law and Economics, 31, 22748, 1988.

Bound, J., C. Cummins, Z. Griliches, B. H. Hall, and A. Jaffe, "Who Does R\&D and Who Patents?" R\&D. Patents, and Productivity, ed., Z. Griliches, University of Chicago Press, Chicago, IL, 1984.

Carmichael, Jeffrey, "The Effects of Mission-Oriented Public R\&D Spending on Private Industry," Journal of Finance, 36(3), 617-27, June 1981.

Cherkasov, G., "The Social Effectiveness of New Technology, "Problems of Economics, 6, 21-36, October 1977.

Colombo, Umberto, "Innovation Strategies for Government and Industry," Technological Innovation: Government/Industry Cooperation, Arthur Gemstenfeld, ed., Assisted by Robert Brainard, New York Chichester, England: Brisbane and Toronto: Wiley, Wiley-Interscience, 209-26, 1979.

Dasgupta, P., 'The Economic Theory of Technology Policy: An Introduction," Economic Policy and Technological Performance, eds., P. Dasgupta and P. Stoneman, Cambridge University Press, Cambridge, MA., 1987.

Dasgupta, P. and P. Stoneman, Economic Policy_and Technological_Performance, Cambridge University Press, Cambridge, MA, 1987.

De Gregori, Thomas R., "Technology and Economic Dependency: An Institutional Assessment," Journal of Economic Issues, 12(2), 467-76, June 1978.

Drulovic, Milosav, "Some Aspects of Technological Innovation Policy," Eastern Eurouean Economics, 3-4, 200-214, Spring-Summer 1982.

Ergas, H., "The Importance of Technology Policy," Economic Policy_and Technological Performance, Eds., P. Dasgupta and P Stoneman, Cambridge University Press, Cambridge, MA., 1987. 
Foster, J. Fagg, "The Effect of Technology on Institutions," Journal of Economic Issues, 15(4), 907-13, December 1981.

Fudenberg, D., R. Gilbert, J. E. Stiglitz, and J. Tirole, "Preemption, Leapfrogging and Competition in Patent Races," Eurouean Economic Review. 22, 3-31, 1983.

Gallini, N. L., and Y. Kotowitz, "Optimal R\&D Processes and Competition,” Economica. 52, 321-34, 1985.

Gallini, N. T. and R. A. Winter, "Licensing in the Theory of Innovations," Rand Journal of Economics, 16, 237-52, Summer 1985.

Ginsburg, Douglas H., "Antitrust, Uncertainty, and Technological Innovation," Antitrust Bulletin, 24(4), 635-86, Winter 1979.

Girvan, Norman, "The Approach to Technology Policy Studies," Social and Economic Studies, 28(1), 1-53, March 1979.

Grossman, G. M. and C. Shapiro, "Research Joint Ventures: An Antitrust Analysis," working paper, Woodrow Wilson School of Public and International Affairs, 1985.

Hamilton, David, "Technology and Institutions Are Neither," Journal of Economic Issues. 525-32, June 1986.

Hill, Christopher T. and James M. Utterback, "Technological Innovation for a Dynamic Economy: Summary and Policy Implications, Technological Innovation for a Dynamic Economy, Christopher T. Hill and James M. Utterback, eds., Pergamon Policy Studies on Science and Technology, No. 50, Pergamon Press in cooperation with the Center for Policy Alternatives, M. I. T., 318-29, 1979.

Jacquemin, A, "Cooperative Agreements in R\&D and European Antitrust Policy," European Economic Review, 32, 551-560, 1988.

Johnson, Harry G., "Aspects of Patents and Licenses as Stilmuli to Innovation," Wehwirtschaftliches Archives, 112(3), 417-28, 1976.

Judd, Kenneth L., "On the Performance of Patents," Econometrica. 53(3), 567-85, May 1985.

Kamien, M. I. and N. L. Schwartz, "Patent Life and R\&D Rivalry," American Economic Review, 64, 183-87, 1974.

Kamien, M. I. and Y. Tauman, "Fees Versus Royalties and the Present Value of a Patent," Quarterly Journal of Economics. 100, 471-91, 1986.

Katz, M. L., "An Analysis of Cooperative Research and Development," Rand Journal of Economics, 17, 527-43, Winter 1986. 
Katz, M. L. and C. Shapiro, "On the Licensing of Innovations," Rand Journal of Economics, 16, 504-20, Winter 1985.

Katz, M. L. and C. Shapiro, "How to License Intangible Property," Quarterlv Jowrnal of Economics, 100, 567-89, 1986.

Lederman, Leonard L., "Government Policy and Innovation in the United States," Technological Innovation: Government/Industry Cooperation. Arthur Gerstenfeld, ed., Assisted by Robert Brainard, New York, Chichester, England; Brisbane and Toronto: Wiley, Wiley-Inter-science, 159-64, 1979.

Lichtenberg, F. R., "The Effect of Government Funding on Private Industrial Research and Development: A Re-Assessment," Journal of Industrial Economics, 36, 97-104, 1987 .

Lurie, Robert S., "R\&D, Innovation and Environmental Regulation: The Case of Copper," American Economist, 27(2), 13-20, Fall 1983.

Magat, Wesley A, "The Effects of Environmental Regulation on Innovation," Law and Contemporary Problems, 43(1), 4-25, Winter-Spring 1979.

Malecki, E. J., "Corporate Organization of R\&D and the Location of Technological Activities," Regional Studies, 14(3), 219-34, 1980.

Matzner, Egon, "Technological and Institutional Innovation," Annals of Public and Co-operative Economy, 56(1-2), 71-80, January-June 1985.

Mcgee, J. S., "Patent Exploitation: Some Economic and Legal Problems," Journal of Law and Economics, 135-62, 1968.

Meza, David, "Invention and the Pursuit of Antitrust," Australian Economic Papers, 17, 103-09, June 1978.

Ordover, Janusz A and Robert D. Willig, “An Economic Definition of Predation: Pricing and Product Innovation,” Yale Law Journal, 91(1), 8-53, November 1981.

Pack, Howard, "Policies to Encourage the Use of Intermediate Technology," Appropriate Technologies for Third World Development: Proceedings of a Conference Held by the International Economic Association at Teheran, Iran, Austin Robinson, ed., St. Martin's Press, 342-66, 1979.

Ruttan, Vernon W., "Induced Institutional Innovation,” Agricultural Economics Research, 31(3), 32-35, July 1979.

Schumpeter, J. A, Capitalism, Socialism, and Democracy, Harper and Brothers Publishers, New York, 1947. 
Sinclair, Peter J. N., "When Will Technical Progress Destroy Jobs?" Oxford Economic Papers, 33(1), 1-18, March 1981.

Sporleder, Thomas L., "Policy Considerations of Emerging Information Technologies," Southern Journal of Agricultural Economics, 16(1), 15-21, July 1984.

Tandon, Pankaj, "Optimal Patents with Compulsory Licensing," Journal of Political Economy,3, 470-86, June 1982.

Teece, D. J., "Profiting from Technological Innovation: Implications for Integration, Collaboration, Licensing, and Public Policy," Ricerche Economiche, XL, 4, 607-43, October-December 1986.

Tinbergen, Jan, “Activities to Promote Appropriate Technology," Conceptual and Policy Framework for Appropriate Industrial Technology, United Nations Industrial Development Organization (UNIDO). UNIDO Monographs on Appropriate Industrial Technology, No. 1, 33-43, 1979.

Yu, Ben T., "Potential Competition and Contracting in Innovation," Journal of Law and Economics, 24(2), 215-38, October 1981. 


\section{INNOVATIONS AND MARKET STRUCTURE}

Bond, E. W. and L. Samuelson, "Durable Goods, Market Structure and the Incentives to Innovate," Economica, 54, 57-67, 1987.

Brander, J. A and B. J. Spencer, "Strategic Commitment with R\&D: The Symmetric Case," Bell Journal of Economics. 14, 225-235, Spring 1983.

Comanor, W. S., "Market Structure Product Differentiation, and Industrial Research," Quarterlv Journal of Economics, 81, 639-57, 1967.

Dasgupta, Partha and Joseph Stiglitz, "Industrial Structure and the Nature of Innovative Activity,” Economic Journal, 358, 266-93, June 1980a.

Dasgupta, P. S. and J. E. Stiglitz, "Uncertainty, Industrial Structure and the Speed of R\&D,” Bell Journal of Economics, 11, 1-28, $1980 \mathrm{~b}$.

De Bondt, Raymond R., "Innovative Activity and Barriers to Entry," European Economic Review, 1, 95-109, October 1977.

Donnenfeld, Shabtai, "Market Uncertainty and the Monopolist Incentive to Innovate," International Journal of Industrial Organization, 1(4), 379-86, December 1983.

Fethke, G. C. and J. J. Birch, "Rivalry and Timing of Innovations," Bell Journal of Economics, 13, 272-79, 1982.

Futia, Carl A, "Schumpeterian Competition," Quarterly Journal of Economics, 94(4), 67595, June 1980.

Goel, R. K., "Innovation, Market Structure, and Welfare: A Stackelberg Model," working paper, University of Houston, June 1986.

Goel, R. K., "Market Structure, Innovations, and Welfare," unpublished dissertation, University of Houston, 1987.

Gort, Michael and Richard A. Wall, "The Effect of Technical Change on Market Structure,” Economic Inquiry, 22(4), 668-75, October 1984.

Grabowski, H. G. and J. M. Vernon, "Pioneers, Imitators, and Generics - A Simulation Model of Schumpeterian Competition," Quarterlv Journal of Economics, 51, 491525, 1987.

Grossman, G. M. and C. Shapiro, "Dynamic R\&D Competition," working paper, Woodrow Wilson School of International Affairs, July 1986a. 
Kamien, M. I. and N. L. Schwartz, "Timing of Innovations Under Rivalry," Econometrica, 40, 43-60, 1972a.

Kamien, M. I. and N. L. Schwartz, "Market Structure and Innovation: A Survey," Journal of Economic Literature. 13, 1-37, 1975.

Kamien, M. I. and N. L. Schwartz, "On the Degree of Rivalry for Maximum Innovative Activity," Quarterlv Journal of Economics, 90, 245-60, 1976.

Kamien, Morton I. and Nancy L. Schwartz, "Potential Rivalry, Monopoly Profits and the Pace of Inventive Activity," Review of Economic Studies, 45(3), 547-57, October 1978.

Kamien, M. I. and N. L. Schwartz, Market Structure and Innovation, Cambridge University Press, Cambridge, MA, 1982.

Kay, Neil M., "Innovation, Markets and Hierarchies," Journal of Economic Studies, 11(2), 44-60, 1984.

Kirchgassner, Gebhard, "Innovations, Market Structure and Market Dynamics: Comment," 142(1), 204-09, March 1986.

Lee, T. and L. L. Wilde, "Market Structure and Innovation: A Reformulation," Quarterly Journal of Economics, 94, 429-36, 1980.

Levin, Richard C., "Technical Change, Barriers to Entry, and Market Structure," Economica, 45, 347-61, November 1978.

Li, Lode, R. D. McKelvey and T. Page, "Optimal Research for Cournot Oligopolists," Journal of Economic Theory, 42, 140-66, 1987.

Lippman, S. A. and K. F. McCardle, "Dropout Behavior in R\&D Races with Learning," Rand Journal of Economics, 18, 287-95, 1987.

Loury, G. C., "Market Structure and Innovation," Quarterly Journal of Economics, 93, 395 $410,1979$.

Lunn, John E., "Research and Development and the Schumpeterian Hypothesis: Alternate Approach," Southern Economic Journal, 49(1), 209-17, July 1982.

Malecki, Edward J., "Locational Trends in R\&D by Large U.S. Corporations, 1965-1977," Economic Geography, 55(4), 309-23, October 1979.

Metcalf, J. S., "Technological Innovation and the Competitive Process," Greek Economic Review, 6(3), 287-316, December 1984. 
Nelson, Richard R. and Sidney G. Winter, "Simulation of Schumpeterian Competition," American Economic Review, 67(1), 271-76, February 1977.

Nelson, R. R. and S. G. Winter, "Forces Generating and Limiting Competition under Schumpeterian Composition, Bell Journal of Economics, 9, 524-48, 1978.

Nelson, Richard R. and Sidney G. Winter, "The Schumpeterian Tradeoff Revisisted," American Economic Review, 72(1), 114-32, March 1982.

Parsons, Gregory L., "Information Technology: A New Competitive Weapon," Sloan Manaaement Review. 25(1), 3-14, Fall 1983.

Reinganum, Jennifer F., "Dynamic Games of Innovation," Journal of Economic Theory, 25(1), 21-41, August 1981.

Reinganum, J. F., "A Dynamic Game of R\&D: Patent Protection and Competitive Behavior," Econometrica, 50, 67188, 1982.

Reinganum, Jennifer F., "Uncertain Innovation and the Persistence of Monopoly," American Economic Review, 73(4), 741-48, September 1983.

Reinganum, J. F., "Innovation and Industry Evolution," Quarterlv Journal of Economics, 99, 81-99, 1985.

Scherer, F. M., "Research and Development Resource Allocation Under Rivalry," Quarterlv Journal of Economics, 81, 359-94, 1967.

Scherer, F. M., Industrial Market Structure and Economic Performance, second edition, Houghton Mifflin Co., Boston, MA, 1980.

Scherer, F. M., Innovation and Growth: Schumneterian Perspectives, The MIT Press, Cambridge, MA, 1984.

Schumpeter, J. A, Capitalism, Socialism, and Democracy, Harper \& Brothers Publishers, New York, 1947.

Shapiro, C., "Patent Licensing and R\&D Rivalry," in Proceedings American Economic Association, 75, 25-30, 1985.

Shrieves, Ronald E., "Market Structure and Innovation: A New Perspective," Journal of Industrial Economics, 26(4), 329-47, June 1978.

Tandon, P., "Rivalry and the Excessive Allocation of Resources to Research," Bell Journal of Economics, 14, 152-65, 1983.

Tandon, Pankaj, "Innovation, Market Structure, and Welfare," American Economic Review, 74(3), 394-403, June 1984. 
Vines, David., "Competitiveness, Technical Progress and Balance of Trade Surpluses," Manchester School of Economics and Social Studies. 48(4), 378-91, December 1980. 


\section{OTHER}

Ayres, Robert U. and Steven M. Miller, "The Role of Technological Change," Journal of Environmental Economics and Management, 7(4), 353-71, December 1980.

Barras, Richard, "A Comparison of Embodied Technical Change in Services and Manufacturing Industry,“ Applied Economics, 18(9), 941-58, September 1986.

Barzel, Yoram, "Optimal Timing of Innovations," Review of Economics and Statistics, 50, 348-55, 1968.

Barzel, Yoram, "Discussion of Innovation Papers," Economic Inquiry, 22(4), 684-85, October 1984.

Benjamin, Robert I., et al., "Information Technology: A Strategic Opportunity," Sloan Management Review, 25(3), 3-10, Spring 1984.

Bhalla, Ajit S. and Dilmus D. James, "Technological Blending: Frontier Technology in Traditional Economic Sectors,” Journal of Economic Issues, 453-62, June 1986.

Bhattacharya, Sudipto and Jay R. Ritter, "Innovation and Communication: Signalling with Partial Disclosure,” Review of Economic Studies, 2, 331-46, April 1983.

Bhattacharya, S. and D. Mookherjee, "Portfolio Choice in Research and Development," Rand Journal of Economics, 17, 594-605, Winter 1986.

Bowman, Ward, 'The Incentive to Invent in Competitive as Contrasted to Monopolistic Industries," Journal of Law and Economics, 1, 227-28, April 1977.

Coke, L. B. and P. I. Gomes, "Critical Analysis of Agricultural Research and Development Institutions and Their Activities," Social and Economic Studies, 28(1), 97-138, March 1979.

Cosimano, Thomas F., 'The Incentive to Adopt Cost Reducing Innovation in the Presence of a Non-Linear. Demand, Curve," Southern Economic Journal, 48(1), 97-102, July 1981.

Dasgupta, P. and E. Maskin, “The Simple Economics of Research Portfolios,” Economic Journal, 97, 581-95, 1987.

Dasgupta, Partha and Joseph Stiglitz, "Resource Depletion under Technological Uncertainty," Econometrica, 49(1), 85-104, January 1981.

De Bandt, Jacques, "Optimal Use of Existing Technology versus New Technology," Journal of Industrial Economics, 26(1), 69-80, September 1977. 
De Bresson, C., 'The Evolutionary Paradigm and the Economics of Technical Change," Journal of Economic Issues, 21, 751-62, 1987.

Dobrov, Gennady M., "Technology as a Form of Organization," International Social Science Journal, 31(4), 585-605, 1979.

Dorfman, N. S., Innovation and Market Structure: Lessons from the Computer and Semiconductor Industries, Ballinger Publishing Co., Cambridge, MA, 1987.

Dunkerley, Harold B., "The Choice of Appropriate Technologies," Finance and Development. 14(3), 36-39, September 1977.

Epstein, Eugene, "Innovation and Growth," Challenge, 27(3), 49-52, July/August 1984.

Evenson, Robert E. and Yoav Kisler, “A Stochastic Model of Applied Research,” Journal of Political Economy, 84(2), 265-81, April 1976.

Farrell, Joseph and Garth Saloner, "Standardization, Compatability, and Innovation," Journal of Economics, 16(1), 70-83, Spring 1985.

Forsyth, David J. C, Norman S. McBain and Robert F. Solomon, "Technical Rigidity and Appropriate Technology in less Developed Countries," World Development, 8(5/6), 371-98, May/June 1980.

Galbraith, J. K. American Capitalism: The Concept of Countervailing Power. Second Edition, Houghton Mifflin Co., Boston, MA., 1956.

Garvin, David A, "Spin-Offs and the New Firm Formation Process," California Management Review, 25(2), 3-20, January 1983.

Gerstenfeld, Arthur, “Technological Forecasting-Rejoinder,” Journal of Business, 2, 243, April 1977.

Ghandour, Marwan and Jurgen Muller, "A New Approach to Technological Dualism," Economic Development and Cultural Change, 25(4), 629-37, July 1977.

Gold, Bela, "Research, Technological Change, and Economic Analysis: A Critical Evaluation of Prevailing Approaches, Quarterly Review of Economics and Business, 17, 7-29, Spring 1977.

Gold, Bela, "Technical Change and Vertical Integration," Managerial and Decision Economics, 7(3), 169-76, September 1986.

Gort, M. and R. A. Wall, "The Evolution of Technologies and Investment in Innovation," Economic Journal, 96, 741-57, 1986. 
Grabowski, Richard, "The Implications of an Induced Innovation Model," Economic Development and Cultural Change, 27(4), 723-34, July 1979.

Griliches, Z., Ed., R\&D. Patents, and Productivity, University of Chicago Press, Chicago, IL, 1984.

Grossman, G. M. and C. Shapiro, “Optimal Dynamic R\&D Programs," Rand Journal of Economics, 17, 581-93, Winter $1986 \mathrm{~b}$.

Hayden, F. Gregory, “An Assessment Dependent upon Technology,” Journal of Economic Issues, 14(1), 211-19, March 1980.

Hill, Christopher T., "Technological Innovation: Agent of Growth and Change," Technological Innovation for a Dynamic Economy, Christopher T. Hill and James M. Utterback, eds., Pergamon Policy Studies on Science and Technology, No. 50, Pergamon Press in cooperation with the Center for Policy Alternatives, M. I. T., 139, 1979.

Hirshleifer, J., "The Private and Social Value of Information and Reward to Innovative Activity," American Economic Review, 61, 561-74, 1971.

Hirshleifer, J., Price Theorv and Applications, Prentice-Hall, New York, 1982.

Hughes, Kirsty S., 'Exports and Innovation: A Simultaneous Model,' European Economic Review, 383-99, April 1986.

Iwai, Katsuhito, "Schumpeterian Dynamics: An Evolutionary Model of Innovation and Imitation," Journal of Economic Behavior and Organization, 5, 159-90, June 1984.

Jarrett, F. G. and R. K. Linder, "Research Benefits Revisited," Review of Marketing and Agricultural Economics, 45(4), 167-78, December 1977.

Jensen, E. J., "Research Expenditures and the Discovery of New Drugs," Journal of Industrial Economics, 36, 83-95, 1987.

Kamien, M. I. and N. L. Schwartz, "Induced Factor Augmenting Technical Progress from a Microeconomic Viewpoint," Econometrica, 37, 668-84, 1969.

Kamien, M. I. and N. L. Schwartz, 'Expenditure Patterns for Risky R\&D Projects", Journal of Applied Probability, 8, 60-73, 1971.

Kamien, M. I. and N. L. Schwartz, "Some Economic Consequences of Anticipating Technical Advance," Western Economic Journal, 123-38, 1972 b.

Kamien, Morton I. and Nancy L. Schwartz, "Optimal Exhaustible Resource Depletion with Endogenous Technical Change," Review of Economic Studies, 45(1), 179-96, February 1978. 
Kamien, M. I. and N. L. Schwartz, "Self-Financing of an R\&D Project," $\underline{\text { American }}$ Economic Review, 68, 252-61, 1978.

Kamien, M. I. and N. L. Schwartz, "A Generalized Hazard Rate, Economics Letters, 5, 245-49, 1980.

Kantorovich, L. V., "Economic Problems of Scientific-Technical Progress," Problems of Economics, 19(4-5-6), 183-211, August-September-October 1976.

Klundert, T. and R. J. Groof, "Economic Growth and Induced Technical Progress," De Economist, 125(4), 505-24, 1977.

Kluyver, Cornelis A, "Innovation and Industrial Product Life Cycles," California Management Review, 1, 21-33, Fall 1977.

Kuznets, Simon, "Technological Innovations and Economic Growth," Growth. Population, and Income Distribution, Selected Essays, 56-99, 1979.

Ladd, George W. and Craig Gibson, "Microeconomics of Technical Change: What's a Better Animal Worth?" American Journal of Agricultural Economics, 2,23640, May 1978.

Leffler, Keith, "Industry Equilibrium in New Product research and Development: A Simple Approach," Economic Inquiry, 19(1), 60-76, January 1981.

Lucas Jr., R. E., “Tests of a Capital Theoretic Model of Technical Change," Economic Studies, 34, 175-90, 1967.

Magat, W. A, "Technological Advance with Depletion of Innovation PossibilitiesImplications for the Dynamics of Factor Shares: A Correction," Economic Journal, 914, December 1980.

Makarov, V. L., "The Introduction of Nontechnical Innovations," Problems of Economics. 27(4), 64-77, August 1984.

Melvin, James R., "Technological Change, Factor Intensity Reversals, and Trade, Economica, 43, 173-80, May 1976.

Nelson, R. R., Understanding Technical Change as an Evolutionary Process, NorthHolland, New York, 1987.

Nelson, Richard R. and Victor D. Norman, "Technological Change and Factor Mix over the Product Cycle: A Model of Dynamic Comparative Advantage," Journal of Development Economics, 4(1), 3-24, March 1977. 
Nelson, R. R. and S. G. Winter, An Evolutionarv Theorv of Economic Change, Belknap Press, Cambridge, MA, 1982.

Palterovich, D., "The Actual Effectiveness of New Technology," Problems of Economics, 23, 2546, February 1981.

Pandey, B. P., "Innovative Firm and Theory of Games," Indian Economic Journal, 27(4), 91-98, April-June 1980.

Peters, M. and R. Winter, "Research and Development with Publicly Observable Outcomes," Journal of Economic Theory, 40, 349-63, 1986.

Riche, Richard W., "Impact of New Electronic Technology," Monthlv Labor Review, 5(3), 37-39, March 1982.

Sato, Kazuo, "Technical Change and the Growth Equilibrium," On the Stability of Contemporary Economic Svstems: Proceedings of the Third Reisenburg Symposium, Oldrich Kyn and Wolfram Schrettl, eds. Mathematical Studies in the Social and Behavioral Sciences, No. 3, 224-46, 1979.

Schouten, D. B. J. and P. J. F. G. Meulendijks, "On Economics and Technical Change," De Economist, 128(2), 226-41, 1980.

Shaffer, Sherrill, "Selective Cost-reducing Innovation," Review of Industrial Organization, 1(3), 240-45, Fall 1984.

Sharp, John A, "Toward an Economic Theory of Technology," International Journal of Social Economics, 7(6), 328-38, 1980.

Solo, Robert A, "The Dilemmas of Technology: A Review Article," Journal of Economic Issues, 13(3), 733-42, September 1979.

Steedman, Ian, "On the 'Impossibility' of Hicks-Neutral Technical Change," Economic Journal, 95(379), 746-58, September 1985.

Stoneman, P. L., "Embodiment of Technological Change and the Speed of Adjustment," Economica, 44( 176), 421-22, November 1977.

Sullivan, B. C., "Economics of Information Technology," International Journal of Social Economics, 12(1), 37-53, 1985.

Telser, Lester G., "A Theory of Innovation of Its Effects," Bell Journal of Economics, 13(1), 69-92, Spring 1982.

Vilenskii, M., "Planning the Effect of Scientific-Technical Progress," Problems of Economics, 21(7), 3-19, November 1978. 
Williamson, Jeffrey G., "Technology, Growth and History," Journal of Political Economy, Part 1, 84(4), 809-20, August 1976.

Zaitsev, B., "Determining the Effectiveness of Technical Innovations," Problems of Economics, 21(2), 23-42, June 1978.

Ziegler, Charles A, "Innovation and the Imitative Entrepreneur," Journal of Economic Behavior and Organization, 6, 103-21, June 1985. 
INTERNAL DISTRIBUTION

ORNL/TM-11155

1. V. D. Baxter

2. L. G. Berry

3. D. J. Bjornstad

4. V. M. Bolinger

5. R. B. Braid

6. M. A. Brown

7. B. L. Bush

8. R. A. Cantor

9. S. A. Carnes

10. J. E. Christian

11. L. M. Cochran

12. F. A. Creswick

13-32. T. R. Curlee

33. S. J. Dale

34. R. C. Devalt

35. R. G. Edwards

36. D. L. Feldman

37. W. Fulkerson

38-57. R. K. Goel

58. I. G. Harrison

59. E. L. Hillsman

60. E. A. Hirst

61. R. B. Honea

62. D. W. Jones
63. C. R. Kerley

64. M. A. Kuliasha

65. P. N. Leiby

66. W. R. Mixon

67. R. D. Perlack

68. C. H. Petrich

69. G. T. Privon

70. S. Rayner

71. J. H. Reed

72. D. E. Reichle

73. L. W. Rickert

74. C. G. Rizy

75. E. Rogers

76. J. R. Sand

77. R. B. Shelton

78. G. G. Stevenson

79. A. F. Turhollow

80. J. W. Van Dyke

81. D. P. Vogt

82. D. B. Waddle

83. Central Research Library

84. Document Reference Section 85-87. Laboratory Records

88. Laboratory Records-ORNL RC

\section{EXTERNAL DISTRIBUTION}

89. J. J. Cuttica, Vice President of Research and Development, Gas Research Institute, 8600 W. Bryn Mawr Avenue, Chicago, IL 60631

90. J. P. Kalt, Professor of Economics, Kennedy School of Government, Harvard University, 79 John F. Kennedy Street, Cambridge, MA 02138

91. David MacFadyen, National Association of Home Builders Research Foundation, 400 Prince Georges Center Blvd., Upper Marlboro, MD 20772-E731

92. D. E. Morrison, Professor of Sociology, Michigan State University, 201 Berkey Hall, East Lansing, MI 48824-11111

93. R. L. Perrine, Professor, Engineering and Applied Sciences, Civil Engineering Department, Engineering I. Room 2066, University of California, Los Angeles, CA 90024 
94. Office of Assistant Manager for Energy Research and Development, DOEORO, Oak Ridge, TN 37830

95-m. OSTI, U.S. Department of Energy, P. 0. Box 2002, Oak Ridge, TN 37831 